\title{
GENDER DIFFERENCES IN NEGOTIATION: \\ EVIDENCE FROM REAL ESTATE TRANSACTIONS
}

\author{
Steffen Andersen \\ Julie Marx \\ Kasper Meisner Nielsen \\ Lise Vesterlund \\ Working Paper 27318 \\ http://www.nber.org/papers/w27318
NATIONAL BUREAU OF ECONOMIC RESEARCH
1050 Massachusetts Avenue
Cambridge, MA 02138
June 2020

Andersen thanks the European Research Council for financial support to the project "Risky Decisions: Revealing Economic Behavior". Marx thanks the Fonnesbech Foundation for financial support. Nielsen thanks the Danish Finance Institute for financial support. Vesterlund thanks the NSF (SES-1330470) for generous financial support. The views expressed herein are those of the authors and do not necessarily reflect the views of the National Bureau of Economic Research.

NBER working papers are circulated for discussion and comment purposes. They have not been peer-reviewed or been subject to the review by the NBER Board of Directors that accompanies official NBER publications.

(C) 2020 by Steffen Andersen, Julie Marx, Kasper Meisner Nielsen, and Lise Vesterlund. All rights reserved. Short sections of text, not to exceed two paragraphs, may be quoted without explicit permission provided that full credit, including $\odot$ notice, is given to the source. 
Gender Differences in Negotiation: Evidence from Real Estate Transactions

Steffen Andersen, Julie Marx, Kasper Meisner Nielsen, and Lise Vesterlund

NBER Working Paper No. 27318

June 2020

JEL No. J16,R30

\section{ABSTRACT}

We investigate negotiations over real estate and find that men secure better prices than women when negotiating to buy and sell property. However, the gender difference declines substantially when improving controls for the property's value; and is eliminated when controlling for unobserved heterogeneity in a sample of repeated sales. Rather than evidence of gender differences in negotiation, the initial difference in prices is evidence that men and women demand different properties. Consistently we find no gender difference in the sales price secured for property inherited from a deceased parent. Provided appropriate controls men and women fare equally well when negotiating over real estate. Our study demonstrates that inference on gender differences in negotiation relies critically on controlling for the value of the negotiated item.

Steffen Andersen

Department of Finance

Copenhagen Business School

Solbjerg Plads 3

DK-2000 Frederiksberg

Denmark

san.fi@cbs.dk

Julie Marx

Department of Finance

Copenhagen Business School

Solbjerg Plads 3

DK-2000 Frederiksberg

Denmark

jma.fi@cbs.dk
Kasper Meisner Nielsen

Department of Finance

Copenhagen Business School

Solbjerg Plads 3

DK-2000 Frederiksberg

Denmark

kmn.fi@cbs.dk

Lise Vesterlund

Department of Economics

University of Pittsburgh

4916 Posvar Hall

Pittsburgh, PA 15260

and NBER

vester@pitt.edu

A data appendix is available at http://www.nber.org/data-appendix/w27318 


\section{Introduction}

This study examines whether men and women secure different outcomes through negotiation for real estate. A classic example of differences in negotiation is seen in the labor market, where gender differences in initiating and engaging in negotiations are noted as contributing to the persistent gender wage gap. For example, the seminal work of Babcock and Laschever (2003) shows in a survey of new graduates that $57 \%$ of the men and only $7 \%$ of the women negotiated the initial compensation offered to them. With an average gain from negotiation of $7.4 \%$, this differential is predicted to result in a substantial wage difference in the long run. ${ }^{1}$ Although negotiation in the labor market is of key concern, it is unfortunately a market where it is challenging to examine gender differences in negotiation. In particular, the researcher has limited information on the value of the employee-employer match and the parties' outside options. The difficulty associated with assessing the 'value' of the negotiated 'item' thus challenges whether gender differences in outcomes necessarily result from differences in willingness and ability to negotiate. ${ }^{2}$

To control for the negotiated item, researchers have instead resorted to the laboratory to examine gender differences in negotiation. Building on a substantial existing literature these studies demonstrate that gender differences in negotiation is context dependent, with the gap varying with the role one holds when negotiating (e.g., Dittrich, Knabe and Leipold, 2014), the gender of the opponent (Eckel and Grossman, 2001; Solnick, 2001; Sutter et al., 2009), ambiguity (HernandezArenaz and Iriberri, 2018), information (Rigdon, 2012), reputation and the potential for backlash (Amanatullah and Morris, 2010; Amanatullah and Tinsley 2013). ${ }^{3}$

While experimental studies are better able to control the negotiated item, it is not clear how the differences documented in these controlled settings extend to the field where negotiations involve larger stakes, are free-form, and where individuals may seek guidance from others. We examine

\footnotetext{
1 These results have led to a push for women to lean-in and negotiate more (Sandberg, 2013). Exley, Niederle and Vesterlund (2019) however show that such a recommendation may be misguided in the presence of positive selection. ${ }^{2}$ Gender differences in negotiation outcomes have also been examined for items that are more easily assessed. Ayres (1991, 1995) and Ayres and Siegelman (1995) report on an audit study for car sales, finding that single women pay higher prices than do single men. Castillo et al. (2013) examine negotiations for taxi rides, finding (as in Ayres, 1991, 1995; and Ayres and Siegelman, 1995) that statistical discrimination drives gender differences in outcomes. However, audit studies instruct buyers on how to negotiate, and thus fail to capture gender differences in the ability and willingness to negotiate. List (2004) instead examines free-form negotiations over sports cards. While finding that statistical discrimination gives rise to a male advantage, the incentives of the study only resulted in transactions $3 \%$ of the time, and thus make it difficult to capture gender differences in negotiation.

${ }^{3}$ Further evidence on gender differences in negotiation depending on circumstances is seen in Andersen et al. (2018), Babcock et al. (2003), Bohnet (2016), Bowles (2013), Bowles and Babcock (2013), Bowles, Babcock and Lai (2007), Bowles and McGinn (2008), Bowles, Babcock and McGinn (2005), Busse, Israeli and Zettelmeyer (2017), Chandra, Gulati and Sallee (2017), Eckel, de Oliveira and Grossman (2008), Erikson and Sandberg (2012), Kray, Thompson and Galinsky (2001), Kray, Galinsky and Thompson (2002), Leibbrandt and List (2015), Small et al. (2007), and for reviews Azmat and Petrongolo (2014), Stuhlmacher and Walters (1999), and Mazei et al. (2015).
} 
real estate negotiations to demonstrate that inference on gender difference in negotiation in the field relies critically on the ability to control for the value of the negotiated item.

Real estate accounts for about $30 \%$ of household expenditure and $50 \%$ of household savings at retirement (Poterba, Venti and Wise, 2011), and is thus a market where gender differences in negotiation can have a substantial effect on financial well-being. ${ }^{4}$ However real estate negotiations are interesting not only because of the financial implications, but also because information on the negotiated item is abundant, and because both men and women are actively engaged as both buyers and sellers in the market. All factors that make it easier to robustly control for heterogeneity and to demonstrate that false inference may result absent such controls.

Using real estate transactions from Denmark, we examine whether men and women secure different prices, and whether these differences are robust to controls for the value of the negotiated item. First, examining negotiation outcomes of 337,685 real estate transactions of Danish properties from 1994 to 2013, we find that single men secure better prices than do single women when they negotiate to buy and sell property. Part of this difference results from single men and women having different characteristics and from them demanding different property characteristics. Second, adding to controls for individual characteristics we use the procedure of Harding, Rosenthal, and Sirmans (2003) to separate the effect of gender differences in demand from that of gender differences in negotiation. Controlling for observable property characteristics, we replicate their results and find that gender differences in negotiation contribute to the inferior prices secured by women. However, this difference is reduced when we include the tax-assessed value of the property to control for the value of the negotiated item and implicitly for characteristics that, while observable to the tax authorities, are unobservable to us as researchers. Third, we find that the effect of gender differences in negotiation on prices is eliminated when looking at repeated sales of the same property. The repeated sales analysis, which is a common approach in real estate economics, effectively controls for time-invariant heterogeneity (e.g., location amenities) in properties by including property fixed effects. The finding that proper controls for the negotiated item eliminate the negotiation effect on prices, suggests that gender differences in demand rather than negotiation is what gives rise to the initial differences in prices. Fourth, to eliminate the price differences that result from men and women demanding (and thus, selling) different properties we use a novel approach to examine differences in sales prices secured for a "random" property. We find that the gender difference in prices is absent when looking at the sales prices secured for property inherited from a deceased parent. The analysis of death sales

\footnotetext{
${ }^{4}$ Relatedly, Wang (2016) finds that real estate, depending on wealth, accounts for between $30 \%$ to $60 \%$ of bequests.
} 
imitates a natural experiment in which properties are randomly assigned to sellers, and substantially reduces (or eliminates) the possibility that seller characteristics influence the item that is being sold. ${ }^{5}$ In eliminating demand effects on the seller side, death sales provide us with an opportunity to better estimate gender differences in transaction prices that are driven by negotiation rather than by gender differences in preferences and demand for property characteristics.

Our findings suggest that initial evidence of gender differences in negotiation over real estate results from insufficient controls for the value of the negotiated item, and from failure to control for the different property characteristics demanded by single men and single women. Provided with proper controls, we find no evidence that single women fare worse than single men when negotiating over real estate.

To further demonstrate the importance of controlling for heterogeneity when drawing inference on gender differences in negotiation, we extend our analysis to evaluate the findings of a more recent US study which finds that single women secure lower unleveraged returns than single men from housing (Goldsmith-Pinkham and Shue, 2019). As with Harding, Rosenthal, and Sirmans (2003), the Danish data replicate the findings of Goldsmith-Pinkham and Shue (2019), that is, until controlling for individual and property characteristics. Once we include controls, the gender differences in real estate returns are eliminated.

In summary, we replicate the findings from two separate US studies that single women secure worse negotiation outcomes for real estate than do single men, however these differences are eliminated in the Danish data once we control for heterogeneity. As comparable controls are missing in the US data, we do not know if the gender gap in negotiation would be similarly eliminated in the US. On one hand, the Danish and US labor markets have similar characteristics in terms of female participation and unemployment, and both markets show differences that are consistent with gender differences in negotiation. ${ }^{6}$ On the other hand, the greater degree of gender equality in Denmark may affect the results (World Economic Forum, 2017, reports that Denmark is ranked $14^{\text {th }}$ on its Gender Gap Index while the United States is ranked $49^{\text {th }}$ ). Despite these potential differences the documented gaps in the US replicate in Denmark. While similar controls

\footnotetext{
${ }^{5}$ We see this as imitating a natural experiment under the assumption that the child's housing preferences are not manifested in the parent's property purchase. Consistent with this assumption, we find that 93\% of inherited real estate is sold within the first year and that this is independent of gender or physical distance between the child and the parent.

${ }^{6}$ Comparing Denmark to the United States we find labor force participation at respectively $80.6 \%$ vs. $78.7 \%$ for men and $76.1 \%$ vs $67.9 \%$ for women, and rates of unemployment at respectively $6.9 \%$ vs. $8.7 \%$ for men and $7.4 \%$ vs $7.2 \%$ for women. Data are drawn from the OECD for 2013 (end of our time period). Although the gender wage gap is smaller in Denmark than the United States (6.3\% versus $17.5 \%)$, the advancement of women to leadership positions is slow in both markets (women account for $23.6 \%$ and $21.7 \%$ of directors in Denmark and United States, respectively, and only $5.9 \%$ and $5.1 \%$ of CEOs are female in Denmark and United States, respectively).
} 
may not eliminate the gap in negotiation in the US, we anticipate that it would reduce it, and our study demonstrates how failure to control for heterogeneity can misguide inference.

In extending the results to other large stake negotiations (e.g., salary, promotion, borrowing) one should be wary of prior evidence that gender differences in negotiation depend critically on the characteristics of the negotiation. For example, the quality of the information available, the one-time interaction, the absence of in-person negotiation and the reliance on professional counsel may well contribute to men and women securing similar outcomes in the real estate market. While the lack of gender differences in real estate negotiation may not extend to all negotiations, we do anticipate that failure to control for heterogeneity will misguide inference in all negotiations. Further, consistent with prior evidence we see our results as pointing to information and training (counsel) as mechanisms that help reduce the effect gender differences in negotiation may have on outcomes. ${ }^{7}$

The study is organized as follows. Section 2 presents the data and descriptive statistics. Section 3 outlines a hedonic model of property prices and explains how we estimate negotiation outcomes in the real estate market. The emphasis is on securing proper controls for the negotiated item when examining all transactions, and when examining only the properties for which we observe repeated sales. Section 4 examines gender differences when we eliminate the potential impact of gender differences in demand on the transaction price. That is, this section presents results from a restricted sample of death sales where beneficiaries sell an inherited property. Section 5 offers concluding remarks and discusses the robustness of our finding that the failure to control for heterogeneity misguides inference on gender differences in real estate transactions. An online appendix provides many supporting details.

\section{Data and descriptive statistics}

Our data cover all residential real-estate transactions in Denmark from 1994 to 2013. The data contain economic and personal information about buyers and sellers, as well as property characteristics and transaction prices. We derive data from six sources made available through Statistics Denmark:

1. Property transactions are from the Danish Tax and Customs Administration (SKAT). SKAT receives the information from The Danish Gazette (Statstidende). Public announcement in The

\footnotetext{
7 See Recalde and Vesterlund (2020) for a review of policies that may reduce the impact of gender differences in negotiation. Note that while real-estate agents may render negotiation advice, the agents' fiduciary responsibility makes it unlikely that the preferences of the agent, rather than those of the client, are reflected in the negotiation.
} 
Danish Gazette is part of the juridical registration of the transfer of ownership, which ensures that we have access to accurate and reliable information on property transactions over the sample period. The transaction data include property prices, transaction dates, as well as property identification numbers used in the housing register described below. ${ }^{8}$

2. Individual characteristics of houses are from the Housing Register (Bygnings- og Boligregister, $B B R$ ), which has detailed information on all properties in Denmark. In addition to property identification numbers and property characteristics, the data contain the personal identification numbers (CPR nummer) of property owners at the end of each year. We identify sellers as owners of a transacted property in the beginning of the year of the transaction, and buyers as owners of the property at the end of the year.

3. Individual and family data are from the official Danish Civil Registration System (CPR Registeret). These records include individual personal identification number (CPR nummer), gender, age, and marital history (marriage, divorce, and widowhood). We use these data to obtain individual characteristics as well as civil status.

4. Income data are from the official records at the Danish Tax and Customs Administration (SKAT). This dataset contains income information by CPR number for the entire Danish population. The tax authorities receive this information directly from the employers, who withhold income tax and pay it directly to SKAT, and who report the actual wages paid to their employees. The data from the tax authorities also contain an assessment of house value, which forms the basis for the property value tax and the municipality land tax. To facilitate the collection of property taxes, the Danish tax authorities (SKAT) assess the value of properties by estimating a property's value as if it were to be sold. The valuation considers factors such as local market conditions, an array of house characteristics, and permissible alternative uses of the land. The assessment is carried out every other year, and in years in which a house is not assessed by the tax authorities, the value is regulated based on the growth in local house prices. The assessment is carried out at the municipal level and incorporates factors that are unobserved in the data from the Housing Register. These factors include access to recreational space (e.g., beach, forest, or lake), distance to public transportation, and other amenities (e.g., schools). We interchangeably refer to the tax authorities' property assessment as tax-assessed value or assessed value.

\footnotetext{
${ }^{8}$ Our transaction data do not contain information about whether realtors represent the buyer and sellers. In Denmark sales in are typically handled through a realtor while purchases are more commonly done without representation. However, our initial analysis fully replicates results from the United States where it is more common to have representation on both sides of the market.
} 
5. Educational records are from the Danish Ministry of Education. All completed (formal and informal) education levels are registered on a yearly basis.

6. Employment status records are from Statistics Denmark's IDA database. An individual's employment status is classified at the end of November each year. Individuals are classified as employed when the majority of their personal income derives from paid employment, and as selfemployed when the majority of their personal income is from self-employment. Individuals outside the labor market are classified as "retired" if the majority of their income is from private or public pensions. Finally, individuals are classified as unemployed if they are neither employed nor selfemployed and have not retired.

Collectively, these data sources allow us to assess transaction data, and link them to buyer and seller characteristics. To correctly identify the agents involved in the transaction, we exclude properties that are traded more than once within a year. To analyze the effect of gender on real estate negotiations, we focus on transactions involving single females and single males and require that each household has an unchanging number of adult members (between 18 and 65 years of age) over a two-year period around the time of the property transaction. This focus ensures that the individuals engaged in a transaction do not change status from being single to being part of a couple, or vice versa. We further restrict the sample to arm's length transactions by excluding transactions between family members. Finally, we focus our analysis on transactions of houses and apartments and exclude, on account of poor controls and small samples, cottages, farms, and cooperative housing. Our gross dataset includes 337,685 observations of real estate transactions in Denmark from 1994 to 2013. Table 1 presents descriptive statistics on buyer and seller characteristics, while Appendix A provides additional details on the sample selection and definition of variables.

[Table 1 here]

Table 1 shows buyer and seller characteristics for all transactions, and for transactions involving single women or single men among buyers and sellers, respectively. ${ }^{9}$ Around 65,000 (71,000) transactions, corresponding to $19 \%(21 \%)$ of all transactions, have a buyer (seller) who is single.

\footnotetext{
${ }^{9}$ As we do not know how couples make decisions, we follow the approach of the literature and study the decisions of singles when examining gender differences. With singles accounting for 35\% of the adult population we see it as important to document differences within this population. Although most singles in our sample were previously in a co-habiting couple (64\% within the last eight years), there are nonetheless observable differences between singles and couples. While we control for such differences it may be asked if gender differences among singles extend to individuals in couples. We address this concern in Section 5 by examining a younger segment of our sample (40 and younger) and find that our results are fully replicable in a sample where observable characteristics between singles and couples are similar.
} 
Among buyers, single women are older, have lower income, have greater wealth, and are better educated, than single men. ${ }^{10}$ The same contrast holds among sellers, where these differences are slightly larger. The difference in individual characteristics of single males and single females highlights the importance of controlling for individual characteristics when assessing the effect of gender on realized real estate prices. Table 2 shows property characteristics for all transactions, and transactions involving single women or single men among buyers and sellers, respectively.

[Table 2 here]

A simple comparison of transaction prices, as shown in Table 2, reveals that single women both buy and sell at higher prices than do single men. Panel A focuses on houses and shows that single women buy houses that cost DKK 175,600 (EUR 23,600) more than those bought by single men. The difference in transaction prices implies that single women buy houses that are $17 \%$ more expensive than those bought by single men. When single women sell, the transaction price is DKK 128,500 (EUR 17,200) higher than houses sold by single men. The difference in transaction prices corresponds to a $10 \%$ gender difference in sales prices. While the finding that women buy and sell at higher prices than men may merely reflect that women purchase more expensive houses, the evidence that the gender gap is smaller when selling than buying may indicate that single women are worse at negotiating: they pay more when buying a property, and while also selling at a higher price, they are not as effective in recapturing the higher purchase price. Absent controls for individual and property characteristics the raw data suggest that, when negotiating over real estate, single women leave DKK 47,100 (EUR 6,300) more on the table than do single men. However, this difference in raw transaction prices may result from single women and single men demanding different property characteristics, either because of differences in financial constraints and other individual characteristics (Table 1), or because their preferences for property characteristics differ.

Potential differences in demand imply that we must control for characteristics of transacted properties to uncover differences in negotiation separate from differences in demand. A closer look at Panel A of Table 2 reveals, however, that gender differences in transaction prices do not correspond to substantial differences in researcher observable house characteristics. Gender differences are small in easily observable property characteristics that are likely to increase the transaction price and are small relative to the $17 \%$ and $10 \%$ gender difference in purchase and sales prices, respectively. When purchasing property, the gender difference in interior size is less than 2 square meters $(2 \%)$, equivalent to 0.04 more rooms $(1 \%)$, and less than 0.03 more bathrooms $(3 \%)$. When selling a property, gender differences are slightly larger. The relatively

${ }^{10}$ Amounts in our study are in 2015 Danish kroner (DKK). One Euro equals 7.45 Danish kroner. 
larger gender differences in property characteristics when selling compared to purchasing, but relatively smaller gender differences in transaction prices when selling compared to purchasing suggests that the gender difference in prices are unlikely to be fully accounted for by observable property characteristics in the Housing Register.

The Housing Register does not capture all characteristics of a transacted property. In particular, the Danish tax authorities have more detailed information available when assessing the value of a property (e.g., local market amenities and conditions, permissible alternative uses of the land). By including the tax authorities' property assessments, we may better control for the value of property characteristics that are not captured in the raw characteristics given in the Housing Register. Using the tax-assessed value of the property in the year prior to the transaction, we find that properties in transactions involving single women have systematically higher assessed value than properties in transactions involving single men. When purchasing a property, the difference of DKK 112,200 (EUR 15,000) in the assessed value corresponds to almost two-thirds of the observed gender difference in transaction prices. When selling, the difference of DKK 96,900 (EUR 13,000) in assessed value corresponds to three-quarters of the gender difference in transaction prices. While using the tax authorities' assessed property value as the benchmark reduces the gender difference in transaction prices substantially, an economically large difference in transactions prices remains. Single women buy properties priced DKK 63,400 (EUR 8,500) above the assessed value relative to single men, but only sell properties at prices DKK 31,600 (EUR 4,200) above the assessed value relative to single men. The triple difference of DKK 31,800 (EUR 4,300) suggests that single women leave $2 \%$ to $3 \%$ of the property's value on the table when they negotiate over real estate.

Panel B focuses on apartments and provides additional insights into the potential gender differences in negotiations. The market for apartments is more liquid and transparent than the market for houses, making it easier for market participants, as well as researchers, to estimate the property's value by finding the price from a recent transaction involving a comparable apartment. ${ }^{11}$

In this more liquid and transparent, and thus less ambiguous, market we continue to find gender differences in prices. ${ }^{12}$ Panel B shows that single women buy apartments at prices that are DKK 120,700 (EUR 16,200) higher and sell apartments at prices that are DKK 99,700 (EUR 13,400) higher than single men. The difference in transaction prices of DKK 21,000 (EUR 2,800)

\footnotetext{
${ }^{11}$ Apartments are transacted more frequently which increases both liquidity and transparency, with the latter resulting from it being easier to find a comparable transaction. In our data the average number of transactions is 1.1 per house and 1.26 per apartment. Further, average transactions in apartment blocks (more than 8 units) equal 3.9.

${ }^{12}$ Past research finds evidence that women fare worse in negotiations that involve more ambiguity (see, e.g., Bowles and McGinn, 2008; Leibbrandt and List, 2015).
} 
remains consistent with single women performing worse in real estate negotiations. Again we notice that observed property characteristics seem small relative to the difference in price. Relative to men, women buy and sell slightly larger apartments. Similarly, using the tax-assessed value, we note that part of the difference likely results from unobservable differences in the properties demanded by single men and women. Single women buy apartments priced DKK 36,900 (EUR $5,000)$ above the assessed value of those bought by single men, but only sell properties at prices DKK 20,100 (EUR 2,700) above the assessed value of those sold by single men. The triple difference suggests that single women leave $1 \%$ to $2 \%$ of the apartment's value on the table, relative to single men.

The main takeaway from Table 2 is thus that gender differences exist in transaction prices. Single women buy at higher prices than those at which they sell, relative to single men. Although part of the gender difference in prices appears to be explained by gender differences in demand for observable and (to us) unobservable property characteristics, differences in transaction prices may also result from gender differences in negotiation. ${ }^{13}$ The identification of potential gender differences in negotiation, whether as a result of differences in bargaining power, ability, or frequency of initiating a negotiation, thus warrants a more careful analysis of our sample of real estate transactions.

\section{Real estate negotiation}

For heterogeneous goods like real estate, the market is thin, and no observed market-clearing price exists. Facilitating negotiation, real estate transactions arise when a buyer's willingness to pay is higher than the seller's reservation price. Thus the observed transaction price will not only depend on the characteristics of the transacted property, but also on the negotiation between buyers and sellers.

One approach to uncovering gender differences in negotiation outcomes is to examine a simple hedonic model of prices on property characteristics. The hedonic model compares the effect of

13 Gender differences in both purchase and sales prices may reflect differences in demand and negotiation. For example, suppose there are no gender differences in negotiation and that women buy houses with a nicer view. If we fail to control for the nicer view then we will see women pay more when they buy and get more when they sell, and these gender difference in prices will only reflect that women demand different houses than those demanded by men. Gender differences in negotiation would arise as gender differences varying between the purchase and sales side, and such differences would appear even if it varied by the individual's role and only appeared on the purchase or sales side (for evidence of role influencing outcomes see e.g., Dittrich et al., 2014; Andersen et al., 2018). 
gender on real estate prices based on the characteristics of buyers and sellers. Table 3 presents results.

[Table 3 here]

We note first that individual characteristics such as income, education or being self-employed are predictive of a higher property price for both buyers and sellers. Further, as expected from the raw means, the simple hedonic approach reveals that single women fare worse than men when negotiating over property. Women leave more money on the table than men when negotiating over houses or apartments. ${ }^{14}$ Controlling first for observable property characteristics, Column 1 of Table 3 reveals that single women buy houses at prices that are $11.0 \%$ greater and sell houses at prices that are $7.0 \%$ greater than those of single men. This difference implies a gender difference in negotiation: single women secure prices that are $4 \%$ worse than single men.

Column 2 of Table 3 shows that the gender difference is small for apartments. Single females pay $7.5 \%$ more when they buy apartments, but also receive $7.1 \%$ higher prices when they sell, relative to single men. As noted above the market for apartments is more liquid and transparent and less ambiguous. Prior research thus suggests that the estimated coefficient on negotiation is expected to be smaller for apartments. Column 3 confirms these findings when we jointly analyze houses and apartments.

An important caveat, as shown by Harding, Rosenthal, and Sirmans (2003) (henceforth HRS), is that the simple hedonic model fails to control for differences in demand for unobserved property characteristics. That is, the estimated gender effect includes both differences in negotiation and in demand. To examine whether gender differences in the realized transaction prices result from differences in negotiation or from men and women demanding different types of properties, we therefore follow the approach of HRS and assume trading symmetry in both negotiation ability and demand. The assumption implies that the negotiation ability is symmetric and independent of whether the individual is a buyer or a seller. ${ }^{15}$ This symmetry assumption helps separate negotiation effects from demand effects by adding differences in seller-buyer characteristics and sums of sellerbuyer characteristics to a standard hedonic model of house prices. The main HRS model for estimating gender differences in negotiation is specified in Equation (1), where the dependent variable is the $\log$ price, $y_{i j t}$ of house (or apartment) $i$ in quarter $j$ in year $t$.

\footnotetext{
${ }^{14}$ Appendix Table E1 expands the hedonic model with improved controls and shows how the gender difference is reduced and ultimately eliminated when controlling for the value of the negotiated property.

15 See Appendix B for a description of the HRS model.
} 


$$
y_{i j t}=\alpha_{j}+\alpha_{t}+\beta X_{i t}+\delta\left(D_{i}^{\text {sell }}-D_{i}^{\text {buy }}\right)+\gamma\left(D_{i}^{\text {sell }}+D_{i}^{\text {buy }}\right)+\varepsilon_{i j t} .
$$

Where $X_{i t}$ is a vector of observed property characteristics for property $i$ at time $t$, and $D_{i}^{\text {sell }}$ and $D_{i}^{b u y}$ are vectors of seller and buyer characteristics. The coefficient $\gamma$ on the sums of the sellerbuyer characteristics is the estimated demand effect, whereas the coefficient $\delta$ on the differences in seller-buyer characteristics is the estimated negotiation effect. To control for seasonality and general market trends in house prices, we further include quarter and year fixed effects $\left(\alpha_{j}\right.$ and $\alpha_{t}$, respectively).

[Table 4 here]

We begin by using the HRS specification, with controls corresponding to Table 3 above. The associated results are shown in Table 4, first separately for houses and apartments, and then when pooling the two. ${ }^{16}$ For each of the three models, in the first column we show the estimated negotiation effects, $\delta$; in the second column, the estimated demand effects, $\gamma$; and in the third column, other controls, including the effect for variables that only refer to buyers (out-of-town and first-time home buyers), where the demand and negotiation effects cannot be separated. Note that a positive negotiation coefficient reflects greater bargaining power, in the sense that the seller sells for more and the buyer pays less, and that a positive demand effect implies greater willingness to pay.

We see in Columns 2 and 5 of Table 4 that for both houses and apartments the demand effect of income, education and being self-employed tends to increase property prices; however, as seen in Columns 1 and 4, such characteristics are also correlated with securing worse outcomes when negotiating over real estate. These results replicate those of HRS, who argue that the inverse relationship between negotiation and income may reflect the effect of diminishing marginal utility of income. ${ }^{17}$ In explaining the gender differences in prices in Table 2 and 3, we see from the indicator on single female in Table 4 the role played by differences in negotiation and in demand. First, Columns 2 and 5 (for houses and apartments, respectively) of Table 4 reveal that single women demand more expensive properties than those demanded by single men. Second, if the observed variation in transaction prices results from women being disadvantaged when bargaining

\footnotetext{
16 See Appendix Table D4 for the distribution of trades between single females, single males, and couples. For brevity, we do not report the estimated coefficients on property characteristics throughout the analysis. Tables with estimated coefficients on property characteristics are available from the authors upon on request.

17 Augmenting the HRS model to include wealth does not alter the coefficient on gender statistically or economically; see Appendix Table C1. We, also note that including wealth does not change the coefficients on, e.g., education or income as these variables capture the relative effect of differences in individual characteristics of buyers and sellers. If individuals have declining marginal utility of wealth, we expect individuals with lower income to negotiate harder (even after controlling for wealth). For comparability, we maintain the HRS specification.
} 
we expect a negative negotiation effect. Consistently, Column 1 in Table 4 shows that relative to single men, single women leave $2.0 \%$ on the table when trading houses. ${ }^{18}$ Column 4 in Table 4 , in contrast, shows that women only leave $0.2 \%$ on the table when trading apartments. In Columns 7,8 , and 9 , we confirm these results when combining houses and apartments into one specification and when including an interaction term between single female and an indicator for apartments. We find a gender difference in negotiation corresponding of $-2.1 \%$ on prices for houses, and a gender difference of $-0.7 \%$ for apartments. That is, we replicate earlier evidence that single women fare worse than single men when negotiating over real estate. ${ }^{19}$

We noted in Table 2 that a large fraction of the gender difference in property prices may be driven by unobserved heterogeneity in the transacted property. To further our understanding of potential gender differences in negotiation, we next aim to better control for unobserved heterogeneity. Specifically, we control for the tax authorities' property value assessments in the year prior to the transaction. Table 5 includes the $\log$ of the tax-assessed value of the property. Looking at the specification for houses, we see in Column 3 that a 10\% increase in the assessed value of the property is associated with a $9.2 \%$ higher transaction price, after controlling for timetrends and observable property characteristics. Thus, heterogeneity in tax-assessed values are similarly valued when the properties are transacted. This finding indicates that the tax-assessed value helps control for the negotiated item, and that it in turn helps us identify gender differences in negotiation.

We see for houses in Column 1 of Table 5 that half of the estimated gender difference in negotiation disappears when we control for the tax- authorities' assessed value of house characteristics that are observable to them. ${ }^{20}$ Comparing the results for the pooled sample in Column 7 of Tables 4 and 5, we see that the estimated gender difference in negotiation decreases from $-2.1 \%$ for houses to $-1.0 \%$ when we control for the assessed value. For apartments, the

\footnotetext{
${ }^{18}$ The effect does not depend on the state of the market. Running a regression with year-gender interactions shows a persistent difference over 20 years, a period that includes both the housing market bubble and bust.

${ }^{19}$ Our result for houses corresponds to those of HRS, who find a gender difference of $3.6 \%$ for American house transactions, when controlling for MSA size. While using more precise controls (municipality size and single/couple status) we replicate the HRS findings of negative effects on negotiation of income, being a couple, college educated, self-employed, and a first-time buyer. The only discrepancy is for age, where HRS find a negative effect (-0.0017) and we find a positive effect (0.001); note however that our estimated coefficient on age is reduced to zero when controlling for assessed property value or for property fixed effects in our repeated sales sample.

20 To examine whether the unobserved property characteristics are correlated with ownership length due to, for example, gender differences in the ability or interest in maintaining the property, we also control for the length of the seller's ownership as well as the interaction between length of ownership and gender (Appendix Table F1). Although transaction prices, as expected, decline with ownership, we find no evidence of gender differences being driven by ownership length.
} 
estimated gender difference in Column 7 is reduced from $-0.7 \%$ to $-0.3 \%{ }^{21}$ This reduction in the coefficient on gender demonstrates that our initial evidence of gender differences in negotiation partially results from insufficient control of the negotiated item.

[Table 5 here]

Results from Tables 4 and 5 highlight that a main caveat to estimating gender differences in negotiation is whether we have properly controlled for property characteristics and thus for potential gender differences in demand. While the hedonic model includes many observable property characteristics, one might be concerned about whether unobserved property characteristics (e.g., location amenities or property quality) correlate with potential gender differences in demand. The HRS model improves on the hedonic model by using buyer-seller sums to control for demand effects. If men and women not only value a particular characteristic differently, but also purchase different property characteristics, then we expect demand coefficients to change once we include unobserved property characteristics as controls. The inclusion of unobserved property characteristics will also change coefficients on bargaining effects because they are estimated relative to the value of the negotiated item. Comparing the estimated coefficients in Table 4 to those in Table 5, we note that the estimated coefficients on the demand effects and on the bargaining effects generally decline, Columns 2 and 1, respectively. Including the assessed value reduces the unobserved heterogeneity in house prices, and highlights that the initial finding of gender difference in negotiation can be attributed to an inability to control for unobserved heterogeneity through the inclusion of buyer and seller characteristics.

A common approach for capturing unobservable property characteristics is to conduct a repeated sales analysis that includes property fixed effects to control for time-invariant heterogeneity (e.g., location amenities or property quality) in properties. When the specification includes property fixed effects, gender differences are estimated using variation in transaction prices of the same property across time, which ensures that the estimated gender difference is not driven by preferences for specific locations or other unobserved time-invariant house characteristics. The remaining sample consists of 97,216 property transactions of houses and apartments that have been traded more than once between 1994 and 2013. We find that the repeated sales sample have characteristics that mirror those of all transactions, and that we replicate

\footnotetext{
${ }^{21}$ Results are similar when controlling for wealth in Appendix Table C2. The reduction in the gender gap in prices is similar for the hedonic model in Appendix E1 where the assessed value decreases the gender gap in prices for houses from $-4 \%$ to $-1.9 \%$ and for apartments from $-0.4 \%$ to $-0.2 \%$.
} 
the results of Table $5 .^{22}$ Strikingly, while the gender difference in negotiation remains in the sample of repeated sales, we see in Table 6 that this is not the case when we include property fixed effects to control for time-invariant heterogeneity in properties.

\section{[Table 6 here]}

The results in Table 6 reveals that the gender differences in negotiation completely disappears, while a substantial demand effect remains. ${ }^{23}$ Thus, no differences exist in the estimated negotiation effect of single men and of single women in the Danish real estate market when we properly control for differences in location amenities and property quality. We find no gender difference for either apartments or houses, suggesting that the estimated gender differences in negotiation in Table 2 to 5 are artefacts of the econometric specification, as opposed to men and women securing different negotiation outcomes. We also note that the coefficient on the single female indicator is quite precisely estimated to be (close to) $0 .{ }^{24}$ The coefficients on the single female indicator do not become statistically insignificant because of large standard errors. Standard errors in Table 6 are of the same order of magnitude as in the baseline results in Table 4.

Figure 1 summarizes the findings of Tables 4 to 6 by plotting the estimated gender difference in negotiations as well as the $95 \%$ confidence interval. The figure indicates that the estimated gender differences diminish when we include the assessed house value as a control, and they disappear when we include property fixed effects to control for unobserved heterogeneity in house quality. A potential concern when examining repeatedly transacted properties is that negotiations over such properties are less ambiguous and that the absence of a gender difference could result from the decrease in ambiguity rather than from improved control of unobservable property characteristics. To address this concern, we first note that the gender difference in negotiation remains in the sample of repeated sales, and that it is eliminated only when we include property fixed effects. ${ }^{25}$ Second, when examining the subsamples of repeated sales with two versus three or more transactions, we find that the gender effect is the same in the two subsamples, and that it is

\footnotetext{
22 See Appendix Table D1 and D2 for the repeated sales equivalents of Table 1 and 2. See also Appendix Table F2 for Table 6 without property fixed effects.

${ }_{23}$ Controlling for wealth provides similar results; see Table C3.

${ }^{24}$ As seen in Appendix Table E1, the results are similar in a simple hedonic model that does not control for differences in demand. For example, when accounting for differences in demand, we found that property assessment controls decrease the gender gap for houses from $2.1 \%$ to $1.0 \%$, and that the gap is further reduced to $0.0 \%$ when looking at repeated sales. Absent controls for differences in demand, the hedonic model on the pooled housing and apartment data shows that property assessment decreases the gender gap from $4.1 \%$ to $2.0 \%$ and that restriction to repeated sales further decreases it to an insignificant $0.0 \%$.

25 The gender gap in the sample of repeated sales is slightly smaller than in the general sample $(-0.8 \%$ versus $-1.0 \%)$. See results in Appendix Table F2.
} 
eliminated in each sample only when including fixed effects. ${ }^{26}$ While we find no evidence to support the argument that a reduction in ambiguity explains our inference from the repeated sales sample, we nonetheless leverage another method of controlling for demand to further validate the finding that gender differences in negotiation does not affect outcomes in real estate negotiations. ${ }^{27}$ In particular we next use a more direct approach to secure that differences in demand do not influence the results. We perform an out-of-sample test of gender differences in transaction prices where individuals are selling a close-to-random property. This imitation of a natural experiment exclusively looks at death sales in which inherited properties are sold by an only child of a deceased parent.

\section{Death sales}

In the previous section, we find no gender differences in negotiation when we control for timeinvariant, but unobserved, characteristics of houses and apartments. To further examine gender differences in negotiation in the real estate market, we next employ a novel research design that imitates a natural experiment in which properties are randomly assigned to sellers. We thereby eliminate potential differences in demand on the sales side. Death sales thus help us estimate gender differences in the realized transaction prices that are more likely to be driven by negotiation.

To identify property owners who have died, we use information from the Danish Cause-ofDeath Register at the Danish National Board of Health (Sundhedsstyrelsen). The source of these data is the official death certificates issued by a doctor immediately after a death. Danish law further obliges the relatives to report the death to their local funeral authority within two days. The funeral authority formally notifies relevant government agencies, including the Central Office for Personal Registration (CPR Registeret) and the probate court (Skifteretten), which supervises the process that transfers legal title of property from the decedent's estate to her beneficiaries. The probate court posts a notice in The Danish Gazette (Statstidende) to advertise for creditors, who in turn have 8 weeks to report their claims on the estate. Following the notice period, assets are either liquidated or valued by the probate court with the purposes of establishing the net worth of the estate,

\footnotetext{
${ }^{26}$ See Appendix Table F3 and F4 for the analysis on the two subsamples of properties that were transacted two versus three or more times.

${ }^{27}$ A hedonic model with buyer and seller fixed effects similarly controls for demand, reveals that the purchase price is $4.0 \%$ higher for a single woman than it is for a single man, and that the sales price is $3.6 \%$ higher for a single woman than a single man. Absent fixed effects the coefficients are $6.9 \%$ and $6.0 \%$ respectively (the comparable gap for the entire sample is $-1.0 \%$ ). Thus the gender gap in prices decreases from $-0.9 \%$ to $-0.4 \%$ after controlling for individual specific demand. A table with estimated coefficients on the hedonic model with buyer and seller fixed effects is available from the authors upon on request.
} 
meeting liabilities, and incurring the estate tax. At the closing of the estate, the residual is paid out to the beneficiaries. According to the Association of Danish Estate Lawyers, estates take, on average, nine months to resolve. During this period, beneficiaries are entitled to appoint a real estate agent to secure the sale of the property.

We restrict the sample to properties sold by the beneficiary of a deceased owner. More specifically, we identify 13,953 houses and apartments in our sample, for which the owner is single or widowed, has only one child, and dies. The sample is obtained by linking owners to their beneficiaries using the data from the Civil Registration System, which allows us to link parents and children using personal identification numbers (CPR nummer). To ensure that the beneficiary has decision power over the estate and, therefore, approves the sale of the inherited property, we focus on inheritance cases with a single beneficiary. This focus simplifies the analysis, as the beneficiary is either single male, single female, or a married couple. ${ }^{28}$

The advantage of analyzing death sales is that the gender of the beneficiary is likely to be determined by nature. ${ }^{29}$ Table 7 shows property characteristics for all death sales, and for beneficiaries who are single men or single women.

\section{[Table 7 here]}

Table 7 shows that the characteristics of inherited houses are close to the characteristics of all houses in our sample. The main difference arises from the fact that death sales consist of properties owned by households comprised of a single and older member. Such properties are typically smaller and older than the average property. We also note that small differences exist in the property characteristics for single male and single female beneficiaries. Single women beneficiaries tend to sell their inherited properties at higher prices than do single male beneficiaries, although property characteristics, as summarized by the tax authorities' assessed value of the property, explain a large part of this difference. If anything, the descriptive statistics do not support gender differences in negotiation in favor of men.

In looking at death sales we are controlling for differences in demand by design, thus we can use a simple hedonic model to estimate gender differences in negotiation. In Column 1 of Table 8

\footnotetext{
28 As in the main analysis, we only include to arm's-length transactions, by excluding transactions between family members. Similar to Andersen and Nielsen (2017) we find that around 93\% of all inherited houses end up being sold at arm's length. More importantly, we find no difference in the propensity to sell the house at arm's length between single female beneficiaries and single male beneficiaries. Thus, the potential bias resulting from transfers of ownership within the family is likely to be small.

${ }^{29}$ Over $95 \%$ of beneficiaries in our death sample are born prior to 1980 , before current techniques to identify the gender of children were widespread. Moreover, no evidence exists, that we are aware of, for a "missing women" problem (Sen, 1992) in Denmark.
} 
we find no significant difference in the sales prices of houses secured by single male and single female sellers. By contrast on the purchase side, that is from the perspective of the deceased parent, we continue to find that single women buy at prices that are greater than that of single men. Note however that in the simple hedonic model, the estimated coefficient of $3.6 \%$ for single women buyers captures both gender differences in negotiation and in demand. Column 2 shows the results for apartments and confirms no gender difference in selling prices. The limited number of inherited apartments however makes it difficult to draw inference from Column 2. Indeed the small sample may help explain why we do not see a gender effect on buying apartments (with only 331 purchases made by single women) ${ }^{30}$

[Table 8 here ]

While our sample of death sales controls for differences in demand and allows us to assess differences in negotiation directly in the hedonic model, it may be of interest to confirm that similar results are secured when using an HRS specification. The challenge in doing so lies with the deceased parent purchasing the property and the beneficiary child selling it. Thus, in extending Equation (1) it may be argued that deceased parent characteristics influence demand and beneficiary child characteristics influence negotiation. The negotiation results are however the same whether we only include the beneficiary seller characteristics, or use the deceased-owner characteristics when determining demand (i.e., using 'deceased-owner'-buyer sums) and beneficiary-seller's characteristics when determining negotiation (i.e., using 'beneficiary-seller'buyer differences). ${ }^{31}$ We find in both cases that the estimated coefficient of the negotiation effect for single females is small and statistically insignificant. ${ }^{32}$

Results from the death sale analysis bolster our finding that gender differences in negotiation in the real estate market disappear once we control for unobserved heterogeneity in housing quality. Women and men realize the same value when they sell property they inherit from their

\footnotetext{
30 Other controls, that are otherwise significant, such as couple seller and seller education, are also statistically insignificant in Column 2 of Table 8.

31 The latter uses "deceased-owner" characteristics because the deceased person's characteristics led to the purchase of the property (i.e., the deceased's willingness to pay and the deceased preferences for the property). The bargaining effect, on the other hand, is given by the beneficiaries, since they are in charge of selling the property. That is the coefficient on 'deceased-owner'-buyer sums, $\gamma$, controls for the demand effect, which is related to the choices of the deceased owner. The coefficient on the 'beneficiary-seller'-buyer differences is the negotiation effect, $\delta$, and relates to the seller beneficiary, who is in charge of the negotiation.

32 Appendix Table F5 reports on the specification with 'deceased-owner'-buyer sums 'beneficiary-seller'-buyer difference, with the negotiation effect on single female for housing being an insignificant $-0.2 \%$. The specification does not lack power despite the small sample size. Almost all of the seller characteristics (e.g., couple indicator, age, income, and education) are both statistically and economically significant. Gender, on the other hand, is statistically and economically insignificant. Further as seen in Appendix Table C4 the results are robust to controlling for wealth.
} 
deceased parents. Eliminating the possibility that seller characteristics are related to property characteristics, we find no gender difference in realized property prices.

\section{Concluding remarks}

Our study contributes to the literature examining whether men and women secure different outcomes through negotiation. We study large stake negotiations using data from the residential real-estate market, where we are able to secure proper controls for value of the item. Our preliminary analysis uncovers a gender difference in negotiation that disappears when we adequately control for heterogeneity in housing. At first glance, females appear to realize worse prices when they buy or sell property. However, women demand property characteristics with higher value assessments, and this helps explain the difference in transacted prices: higher purchase and sales prices for single women than for single men. Our initial finding that females leave $2.1 \%$ on the table when they negotiate declines to $1.0 \%$ when we use the tax authorities' assessments of property values to control for unobserved heterogeneity. When we further focus on the subset of properties with repeated sales in our data, for which we can control for timeinvariant heterogeneity in quality (e.g., location) by including property fixed effects, the gender difference disappears. Finally, we use a novel procedure to control for differences in demand. In particular we confirm our findings by examining beneficiary sales of inherited properties seeing these as sales approximating randomly assigned properties. We find that single male and single female beneficiaries realize the same sales prices when they are selling inherited properties. This analysis rules out the possibility that the estimated gender difference is confounded by differences in demand for housing. We conclude that men and women secure the same outcomes when negotiating over real estate. Our results demonstrate how failure to properly control for the negotiated item may lead to misguided inference on gender differences in negotiation.

The key implication of our findings is that studies of gender differences in negotiation must control for both individual characteristics that drive demand and for the characteristics of the negotiated item. To underscore the importance of this finding we extend our analysis to a recent study of gender differences in return from real-estate negotiations in the US. Using the CoreLogic data on real-estate transactions Goldsmith-Pinkham and Shue (2019) find that the return secured by women is 1 to 2 percentage point lower than that secured by men. We replicate their finding when applying their analysis to our data. Women in Denmark earn a 1.7 percentage point lower 
return per year compared to men. ${ }^{33}$ In contrast to the data used in Goldsmith-Pinkham and Shue (2019), our data contains information on individual characteristics (e.g., age, income, and education) as well as property characteristics. These differences are expected to influence the estimated gender differences in returns. Controlling for individual characteristics we see a $75 \%$ reduction in estimated gender gap, a gap that is fully eliminated when we further control for house characteristics and the tax-assessed value of the property. In fact, we find a precisely estimated gender difference of $0 \%$ in the return to real estate when the specification includes controls for individual and house characteristics. ${ }^{34}$ In extending our examination to that of Goldsmith-Pinkham and Shue (2019), we replicate the gender differences in unleveraged returns documented in the US data, but also find that these differences are eliminated when including controls that are not available in the US data. Thus, using two different analyses our study points to the importance in controlling for heterogeneity and shows that single men and single women secure the same outcomes in the Danish real estate market.

As we do not know how couples make decisions, our analysis explores gender differences by examining outcomes for singles. With singles accounting for $35 \%$ of the adult population and for $20 \%$ of the transactions in our sample, it is important to document that in contrast to initial evidence single women are not disadvantaged when negotiating for real estate. Nonetheless it may be questioned whether potential differences result from selection in to (or out of) being a couple, or from being in a couple. Although the vast majority of singles previously were in a couple, both observable and unobservable characteristics may vary between singles and individuals in couples. ${ }^{35}$ Indeed single females in our sample are less likely to have school-age children, are older and have greater wealth than females in couples. ${ }^{36}$ Although we control for individual characteristics throughout our analysis, we examine if our results hold in a younger population where singles are more similar to individuals in couples. Looking at the sample of those age 40 and younger, where the differences in observable characteristics are smaller between singles and individuals in couples, our results replicate, by documenting a substantial gender gap among singles which is eliminated

\footnotetext{
${ }^{33}$ For comparison Goldsmith-Pinkham and Shue (2019) find absent controls that single women secure a return which is $1.6 \%$ lower than that of single men. After including Zip-Year-Month fixed effects the estimate drops to 1.3\%, and further drops to $1.1 \%$ when controlling for holding length. As shown in Columns 1 to 3 in Appendix Table F6 the corresponding estimates in our data are $1.7 \%, 1.2 \%$ and $0.8 \%$, respectively.

34 See Appendix Table F6 Column 4 through 6. To mirror our earlier results we do not control for wealth, however the results are identical when also controlling for wealth.

35 Of the population of singles 35\% were in a couple within the last three years and $64 \%$ within the last eight years; for those 40 and younger the rates are $38 \%$ and $71 \%$, respectively. Further, the likelihood of having been in a couple is comparable for men and women.

36 See Appendix Table D5.
} 
when controlling for heterogeneity. ${ }^{37}$ Thus we find similar results when looking at a sample where differences between singles and individuals in couples are small.

As noted previously it may be questioned how our results on real estate negotiations in Denmark extend to the US or to negotiations in general. Using the same procedures and similar controls to those of two US studies we replicate the finding that real estate negotiations put women at a disadvantage. While this gender difference is eliminated when using the superior controls offered in the Danish data, we do not know if similar controls would eliminate the gender gap documented in the US data. However we see it as unlikely that the inference drawn absent such controls is not similarly misguided. The lesson should be the same when extending the results to other forms of negotiations. With previous research showing that gender differences in negotiation outcomes depend critically on the characteristics of the bargaining environment, we recognize that gender differences in negotiations are likely to have a larger impact in negotiations that are inperson and where the outcome is more ambiguous, dependent on confidence, and where there is greater potential for back lash (e.g., salary and promotions see Recalde and Vesterlund, 2020, for review). While the absence of a gender gap in real estate negotiations is unlikely to extend to all negotiations, our study suggests that failure to control for heterogeneity is likely to lead to biased estimates of gender difference independent of the negotiation characteristics. ${ }^{38}$ Furthermore in thinking about initiatives that may reduce the impact of gender differences in negotiations we see it as informative for future policy that men and women secure the same outcomes when negotiating in a market where they can secure guidance and information on negotiated outcomes from a third party. While we are unable to determine whether the absence of a gender gap results from there being a realtor and information being accessible, we see the results from the real estate market as suggestive of the institutional changes that may help men and women secure the same outcomes when negotiating in other markets.

\footnotetext{
${ }^{37}$ See Appendix Table D6, as well as Table F7 through F9. The effect on single female decreases from $-1.7 \%$ to $-1.2 \%$ when controlling for property assessment, and to $-0.4 \%$ in the sample of repeated sales with property fixed effects (compared to $-2.1 \%,-1.0 \%$, and $0.0 \%$ for the entire sample).

${ }^{38}$ For example, Bowles, Babcock, and McGinn (2005) highlight how the gender gap in negotiation depends on the constraints and triggers of the particular negotiation. As noted in the introduction gender differences in negotiation may depend on the role one holds when negotiating, the gender of the opponent, ambiguity, information, and the potential for backlash.
} 


\section{References}

Amanatullah, E.T., and M.W. Morris. 2010. Negotiating gender roles: Gender differences in assertive negotiating are mediated by women's fear of backlash and attenuated when negotiating on behalf of others. Journal of Personality and Social Psychology 98(2): 256-267. https://doi.org/10.1037/a0017094

Amanatullah, E.T., and C.H. Tinsley. 2013. Punishing female negotiators for asserting too much... or not enough: Exploring why advocacy moderates backlash against assertive female negotiators. Organizational Behavior and Human Decision Processes 120(1): 110-122. https://doi.org/10.1016/j.obhdp.2012.03.006

Andersen, S., Ertac, S., Gneezy, U., List, J.A., Maximiano, S., 2018. On the cultural basis of gender differences in negotiation. Experimental Economics 21(4), 757-778.

Gender, competitiveness, and socialization at a young age: Evidence from a matrilineal and a patriarchal society. The Review of Economics and Statistics 95, 1438-1443. https://doi.org/10.1162/REST a 00312

Andersen, S., and K. M. Nielsen. 2017. Fire sales and house prices: Evidence from estate sales due to sudden death. Management Science 63: 201-212. https://doi.org/10.1287/mnsc.2015.2292

Ayres, I. 1991. Fair driving: Gender and race discrimination in retail car negotiations. Harvard Law Review 104: 817-872. https://doi.org/10.2307/1341506

Ayres, I. 1995. Further evidence of discrimination in new car negotiations and estimates of its cause. Michigan Law Review 94: 109-147. https://doi.org/10.2307/1289861

Ayres, I., and P. Siegelman. 1995. Race and gender discrimination in bargaining for a new car. The American Economic Review 85(3): 304-321.

Azmat, G., and B. Petrongolo. 2014. Gender and the labor market: What have we learned from field and lab experiments?" Labour Economics, 30: 32-40.

Babcock, L., and S. Laschever. 2003. Women don't ask: Negotiation and the gender divide. Princeton, NJ: Princeton University Press.

Babcock, L., S. Laschever, M. Gelfand, and D. Small. 2003. Nice girls don't ask. Harvard Business Review 81: 14-16.

Bohnet, I. 2016. What Works. Gender Equality by Design. Massachusetts, MA: Harvard University Press. 
Bowles, H.R., 2013. Psychological Perspectives on Gender in Negotiation, in: The SAGE Handbook of Gender and Psychology. SAGE Publications, Ltd, 1 Oliver's Yard, 55 City Road London EC1Y 1SP, pp. 465-483. https://doi.org/10.4135/9781446269930.n28

Bowles, H.R., and L. Babcock. 2013. How can women escape the compensation negotiation dilemma? Relational accounts are one answer. Psychology of Women Quarterly 37: 80-96. https://doi.org/10.1177/0361684312455524

Bowles, H.R., L. Babcock, and L. Lai. 2007. Social incentives for gender differences in the propensity to initiate negotiations: Sometimes it does hurt to ask. Organizational Behavior and Human Decision Processes 103: 84-103. https://doi.org/10.1016/j.obhdp.2006.09.001

Bowles, H.R., L. Babcock, and K.L. McGinn. 2005. Constraints and triggers: Situational mechanics of gender in negotiation. Journal of Personality and Social Psychology 89(6): 951-965.

Bowles, H.R., and K. L. McGinn. 2008. Gender in job negotiations: A two-level game. Negotiation Journal 24(4): 393-410.

Bohnet, I. 2016. What works: Gender equality by design. Cambridge, MA: Belknap Press of Harvard University Press.

Busse, M.R., A. Israeli, and F. Zettelmeyer. 2017. Repairing the damage: The effect of price knowledge and gender on auto repair price quotes. Journal of Marketing Research 54: 75-95. https://doi.org/10.1509/jmr.13.0291

Castillo, M., R. Petrie, M. Torero, and L. Vesterlund. 2013. Gender differences in bargaining outcomes: A field experiment on discrimination. Journal of Public Economics 99: 35-48. https://doi.org/10.1016/j.jpubeco.2012.12.006

Chandra, A., S. Gulati, and J.M. Sallee. 2017. Who loses when prices are negotiated? An analysis of the new car market: Who loses when prices and negotiated? The Journal of Industrial Economics 65: 235-274. https://doi.org/10.1111/joie.12125

Dittrich, M., A. Knabe, and K. Leipold. 2014. Gender differences in experimental wage negotiations. Economic Inquiry 52: 862-873. https://doi.org/10.1111/ecin.12060

Eckel, C., A.C.M.D. Oliveira, and P.J. Grossman. 2008. Gender and negotiation in the small: Are women (perceived to be) more cooperative than men? Negotiation Journal 24: 429-445. https://doi.org/10.1111/j.1571-9979.2008.00196.x

Eckel, C.C., and P.J. Grossman. 2001. Chivalry and solidarity in ultimatum games. Economic Inquiry 39: 171-188. https://doi.org/10.1111/j.1465-7295.2001.tb00059.x 
Eriksson, K.H., and A. Sandberg. 2012. Gender differences in initiation of negotiation: Does the gender of the negotiation counterpart matter? Negotiation Journal 28(4): 407-428.

Exley, C., M. Niederle, and L. Vesterlund. 2019. Knowing when to ask: The cost of leaning in. forthcoming Journal of Political Economy

Harding, J.P., S.S. Rosenthal, and C.F. Sirmans. 2003. Estimating bargaining power in the market for existing homes. Review of Economics and Statistics 85: 178-188.

Hernandez-Arenaz, I., and N. Iriberri. 2018. Women ask for less (only from men): Evidence from bargaining in the field. Journal of Economic Behavior \& Organization 152: 192-214. https://doi.org/10.1016/i.jebo.2018.06.010

Kray, L.J., A.D. Galinsky, and L. Thompson. 2002. Reversing the gender gap in negotiations: An exploration of stereotype regeneration. Organizational Behavior and Human Decision Processes 87: 386-410. https://doi.org/10.1006/obhd.2001.2979

Kray, L.J., L. Thompson, and A. Galinsky. 2001. Battle of the sexes: Gender stereotype confirmation and reactance in negotiations. Journal of Personality and Social Psychology 80: 942-958. https://doi.org/10.1037/0022-3514.80.6.942

Leibbrandt, A., and J. A. List. 2015. Do women avoid salary negotiations? Evidence from a largescale natural field experiment. Management Science 61 (9): 2016-2024.

List, J. 2004. The nature and extent of discrimination in the marketplace: Evidence from the field, The Quarterly Journal of Economics 119 (1): 49-89.

Mazei, J., J. Hüffmeier, P.A. Freund, A.F. Stuhlmacher, L. Bilke, and G. Hertel. 2015. A metaanalysis on gender differences in negotiation outcomes and their moderators. Psychological Bulletin 141: 85-104. https://doi.org/10.1037/a0038184

Poterba, J., S. Venti and D. Wise. 2011. The composition and drawdown of wealth in retirement. Journal of Economic Perspectives 25 (4): 95-118.

Recalde, M., and L. Vesterlund. 2020. Gender differences in negotiation and policy for improvement, forthcoming Bargaining: Current Research and Future Directions, edt. Karagözoğlu, E, Hyndman, K.

Rigdon, M.L. 2012. An experimental investigation of gender differences in wage negotiations (SSRN Scholarly Paper No. ID 2165253). Social Science Research Network, Rochester, NY.

Sandberg, S. 2013. Lean in: Women, work, and the will to lead. New York : Alfred A. Knopf. 
Sen, A. 1992. Missing women. BMJ 304: 587-588.

Small, D.A., M. Gelfand, L. Babcock, and H. Gettman. 2007. Who goes to the bargaining table? The influence of gender and framing on the initiation of negotiation. Journal of Personality and Social Psychology 93: 600-613. https://doi.org/10.1037/0022-3514.93.4.600

Solnick, S.J., 2001. Gender differences in the ultimatum game. Economic Inquiry 39, 189-200. https://doi.org/10.1111/j.1465-7295.2001.tb00060.x

Stuhlmacher, A. F., and A.E. Walters. 1999. Gender differences in negotiation outcome: A metaanalysis. Personnel Psychology 52: 653-677.

Sutter, M., R. Bosman, M.G. Kocher, and F. van Winden. 2009. Gender pairing and bargainingBeware the same sex! Exp Econ 12: 318-331. https://doi.org/10.1007/s10683-009-9217-9

Wang, K. 2016. Bequest in the US: Patterns, motives and tax policy. Working paper.

World Economic Forum. 2017. The global gender gap report: 2017. World Economic Forum, Geneva. 
Figure 1: Summary of results

This figure plots the point estimates and 95-percent confidence intervals of female negotiation across Table 4 to Table 6.

\section{HOUSES}

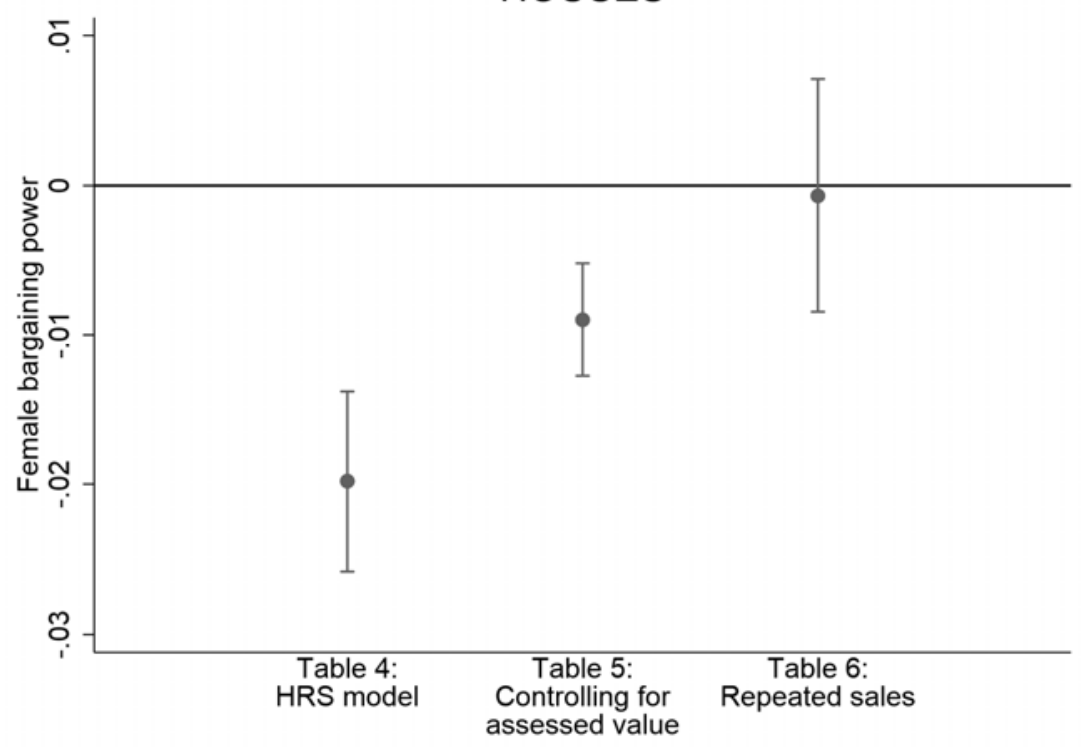

APARTMENTS

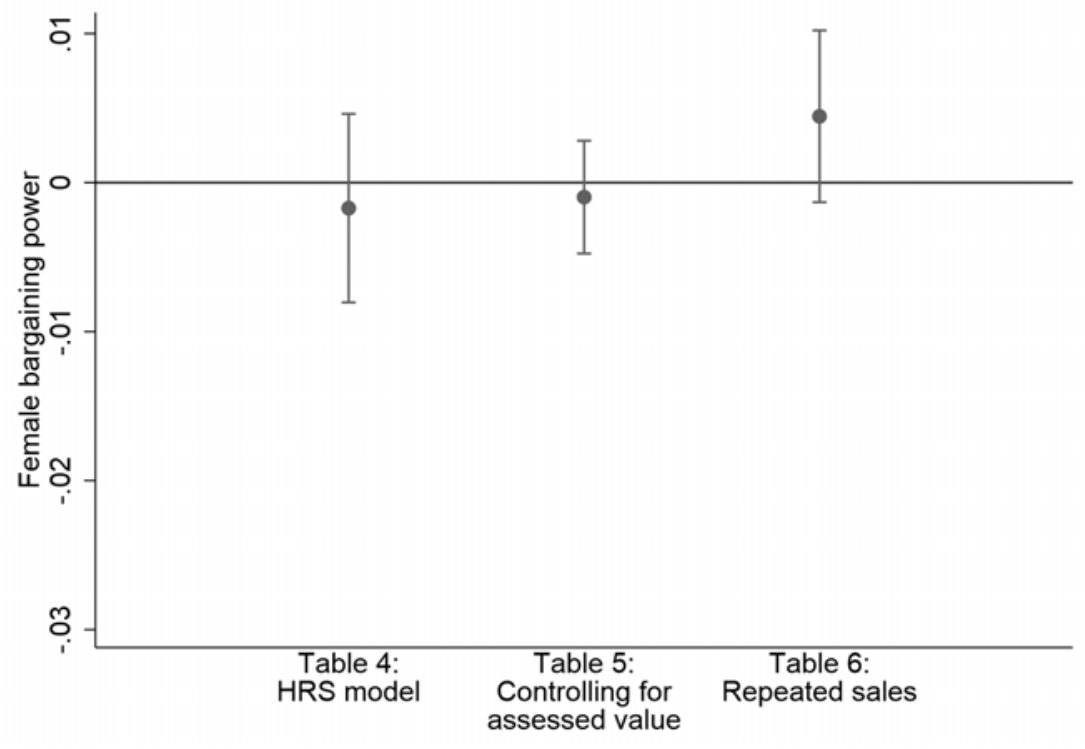




\section{Table 1: Buyer and seller characteristics}

This table shows mean characteristics of buyers and sellers in 337,685 property transactions from 1994 to 2013, in which both buyers and sellers are between 18 and 65 years of age and did not experience a change in the composition of adult household members around the time of transaction. Households consist of one or two adults living together and the number of children living with them. A household takes part in a transaction if at least one adult in the household buys or sells property. Buyers are identified as the owners of the property the year after the transaction, while sellers are identified as the owners of the property, registered January 1, in the year of the transaction. We take household characteristics from December 31 in the year before the transaction year. Age is the mean age of the adult household members. Income and net wealth are household totals in 2015 prices, winsorized at 1 percent in both ends, and presented in millions Danish kroner. College is the share of adult household members with a college degree. Self-employed is the share of adult household members that are self-employed. All shares take values $0,0.5$, or 1 . School-age children is a dummy for having children between 5 and 15 years old (the children do not necessarily live in the household). First-time buyer is an indicator on no member of the household previously having owned real estate. Out-of-town buyer is an indicator on the household purchasing property in a municipality they did not previously live in. Standard deviations are presented in parentheses for non-indicator variables. t-statistics are in brackets. ${ }^{* * *}$ indicates significance at the $1 \%$ level. See Appendix Table D3 for differences in indicator variables.

\begin{tabular}{|c|c|c|c|c|c|c|c|c|}
\hline & \multicolumn{4}{|c|}{ Buyers } & \multicolumn{4}{|c|}{ Sellers } \\
\hline & All & $\begin{array}{c}\text { Single } \\
\text { women } \\
(1)\end{array}$ & $\begin{array}{c}\text { Single } \\
\text { men } \\
(2)\end{array}$ & $\begin{array}{l}\text { Difference } \\
\text { (1)-(2) }\end{array}$ & All & $\begin{array}{c}\text { Single } \\
\text { women } \\
(3)\end{array}$ & $\begin{array}{c}\text { Single } \\
\text { men } \\
(4)\end{array}$ & $\begin{array}{l}\text { Difference } \\
\text { (3)-(4) }\end{array}$ \\
\hline Age & $\begin{array}{c}38.83 \\
(11.36)\end{array}$ & $\begin{array}{c}41.86 \\
(12.21)\end{array}$ & $\begin{array}{c}36.66 \\
(11.62)\end{array}$ & $\begin{array}{c}5.20^{* * *} \\
{[55.4]}\end{array}$ & $\begin{array}{c}43.67 \\
(11.82)\end{array}$ & $\begin{array}{c}49.46 \\
(11.69)\end{array}$ & $\begin{array}{c}43.46 \\
(12.19)\end{array}$ & $\begin{array}{c}6.01^{* * *} \\
{[67.21]}\end{array}$ \\
\hline Income (million DKK) & $\begin{array}{c}0.67 \\
(0.39)\end{array}$ & $\begin{array}{c}0.36 \\
(0.23)\end{array}$ & $\begin{array}{r}0.38 \\
(0.27)\end{array}$ & $\begin{array}{c}-0.02^{* * *} \\
{[-10.44]}\end{array}$ & $\begin{array}{c}0.66 \\
(0.37)\end{array}$ & $\begin{array}{l}0.34 \\
(0.21)\end{array}$ & $\begin{array}{c}0.39 \\
(0.27)\end{array}$ & $\begin{array}{c}-0.04^{* * *} \\
{[-24.50]}\end{array}$ \\
\hline Net wealth (million DKK) & $\begin{array}{c}0.48 \\
(1.49)\end{array}$ & $\begin{array}{r}0.51 \\
(1.29)\end{array}$ & $\begin{array}{c}0.33 \\
(1.17)\end{array}$ & $\begin{array}{c}0.18^{* * *} \\
{[18.65]}\end{array}$ & $\begin{array}{c}0.63 \\
(1.58)\end{array}$ & $\begin{array}{l}0.80 \\
(1.39)\end{array}$ & $\begin{array}{c}0.54 \\
(1.37)\end{array}$ & $\begin{array}{c}0.26^{* * *} \\
{[25.54]}\end{array}$ \\
\hline College & 0.28 & 0.34 & 0.20 & $\begin{array}{c}0.14^{* * *} \\
{[40.65]}\end{array}$ & 0.25 & 0.27 & 0.18 & $\begin{array}{c}0.09^{* * *} \\
{[28.69]}\end{array}$ \\
\hline Self-employed & 0.04 & 0.03 & 0.03 & $\begin{array}{c}0.00 \\
{[-1.28]}\end{array}$ & 0.04 & 0.03 & 0.04 & $\begin{array}{l}-0.01^{* * *} \\
{[-9.98]}\end{array}$ \\
\hline School-age children & 0.28 & 0.18 & 0.14 & $\begin{array}{c}0.04^{* * *} \\
{[12.39]}\end{array}$ & 0.30 & 0.14 & 0.19 & $\begin{array}{c}-0.05^{* * *} \\
{[-17.62]}\end{array}$ \\
\hline First-time buyer & 0.30 & 0.40 & 0.50 & $\begin{array}{c}-0.10^{* * *} \\
{[-25.41]}\end{array}$ & & & & \\
\hline Out-of-town buyer & 0.45 & 0.40 & 0.39 & $\begin{array}{c}0.00 \\
{[0.97]}\end{array}$ & & & & \\
\hline $\mathrm{N}$ & 337,685 & 28,720 & 36,232 & & 337,685 & 35,007 & 36,413 & \\
\hline
\end{tabular}




\section{Table 2: Property characteristics}

This table shows characteristics of property transactions from 1994 to 2013, separately for houses and apartments. Price is the realized sales price, and assessed value is the assessed value of the property from the Danish tax authorities prior to the sale. Both prices and assessed value are measured in thousand year-2015 DKK. (One Euro equals 7.45 DKK.) Interior size and Lot size are measured in square meters. House age and building age are measured in years. Rooms and batbrooms are count variables. Rural indicates a rural area. Standard deviations are presented in parentheses for non-indicator variables. t-statistics are in brackets. ${ }^{* * *}$ indicates significance at the $1 \%$ level.

\begin{tabular}{|c|c|c|c|c|c|c|c|}
\hline & \multirow[b]{2}{*}{ All } & \multicolumn{3}{|c|}{ Buyers } & \multicolumn{3}{|c|}{ Sellers } \\
\hline & & $\begin{array}{c}\text { Single } \\
\text { women } \\
(1)\end{array}$ & $\begin{array}{c}\text { Single } \\
\text { men } \\
(2)\end{array}$ & $\begin{array}{l}\text { Difference } \\
\text { (1)-(2) }\end{array}$ & $\begin{array}{c}\text { Single } \\
\text { women } \\
(3)\end{array}$ & $\begin{array}{c}\text { Single } \\
\text { men } \\
(4)\end{array}$ & $\begin{array}{l}\text { Difference } \\
\text { (3)-(4) }\end{array}$ \\
\hline \multicolumn{8}{|l|}{ A. Houses } \\
\hline Number of transactions & 269,350 & 16,322 & 19,676 & & 25,449 & 25,275 & \\
\hline Price $(1,000 \mathrm{DKK})$ & $\begin{array}{c}1514.08 \\
(1097.75)\end{array}$ & $\begin{array}{c}1185.41 \\
(900.89)\end{array}$ & $\begin{array}{l}1009.83 \\
(912.03)\end{array}$ & $\begin{array}{l}175.58^{* * *} \\
{[18.28]}\end{array}$ & $\begin{array}{c}1365.16 \\
(1049.74)\end{array}$ & $\begin{array}{c}1236.70 \\
(1018.74)\end{array}$ & $\begin{array}{l}128.46^{* * *} \\
{[13.98]}\end{array}$ \\
\hline Assessed value (1,000 DKK) & $\begin{array}{c}1213.08 \\
(834.63)\end{array}$ & $\begin{array}{c}973.42 \\
(702.03)\end{array}$ & $\begin{array}{c}861.24 \\
(686.52)\end{array}$ & $\begin{array}{l}112.17^{* * *} \\
{[15.28]}\end{array}$ & $\begin{array}{c}1149.97 \\
(840.28)\end{array}$ & $\begin{array}{c}1053.08 \\
(791.43)\end{array}$ & $\begin{array}{l}96.89^{* * *} \\
{[13.37]}\end{array}$ \\
\hline Interior size $\left(\mathrm{m}^{2}\right)$ & $\begin{array}{l}121.46 \\
(45.89)\end{array}$ & $\begin{array}{l}100.81 \\
(36.72)\end{array}$ & $\begin{array}{l}99.47 \\
(38.00)\end{array}$ & $\begin{array}{c}1.34^{* * *} \\
{[3.37]}\end{array}$ & $\begin{array}{l}116.32 \\
(45.44)\end{array}$ & $\begin{array}{l}112.62 \\
(45.68)\end{array}$ & $\begin{array}{l}3.69^{* * *} \\
{[9.12]}\end{array}$ \\
\hline Lot size $\left(\mathrm{m}^{2}\right)$ & $\begin{array}{c}1030.20 \\
(2319.69)\end{array}$ & $\begin{array}{r}794.18 \\
(1137.47)\end{array}$ & $\begin{array}{c}970.11 \\
(1440.14)\end{array}$ & $\begin{array}{c}-175.93^{* * *} \\
{[-12.67]}\end{array}$ & $\begin{array}{c}1004.06 \\
(1504.45)\end{array}$ & $\begin{array}{c}1087.06 \\
(4290.55)\end{array}$ & $\begin{array}{l}-83.00^{* * *} \\
{[-2.91]}\end{array}$ \\
\hline House age (years) & $\begin{array}{c}45.01 \\
(35.16)\end{array}$ & $\begin{array}{c}53.05 \\
(40.78)\end{array}$ & $\begin{array}{c}56.92 \\
(41.15)\end{array}$ & $\begin{array}{l}-3.86^{* * *} \\
{[-8.90]}\end{array}$ & $\begin{array}{c}50.68 \\
(36.64)\end{array}$ & $\begin{array}{c}52.21 \\
(39.26)\end{array}$ & $\begin{array}{l}-1.53^{* * *} \\
{[-4.54]}\end{array}$ \\
\hline Rooms (\#) & $\begin{array}{c}4.42 \\
(1.33)\end{array}$ & $\begin{array}{c}3.82 \\
(1.15)\end{array}$ & $\begin{array}{c}3.78 \\
(1.22)\end{array}$ & $\begin{array}{l}0.04^{* * *} \\
{[3.09]}\end{array}$ & $\begin{array}{c}4.28 \\
(1.34)\end{array}$ & $\begin{array}{c}4.15 \\
(1.34)\end{array}$ & $\begin{array}{c}0.12^{* * *} \\
{[10.26]}\end{array}$ \\
\hline Bathrooms (\#) & $\begin{array}{c}1.38 \\
(0.56)\end{array}$ & $\begin{array}{l}1.18 \\
(0.44)\end{array}$ & $\begin{array}{c}1.16 \\
(0.44)\end{array}$ & $\begin{array}{l}0.03^{* * *} \\
{[5.66]}\end{array}$ & $\begin{array}{c}1.32 \\
(0.55)\end{array}$ & $\begin{array}{c}1.28 \\
(0.53)\end{array}$ & $\begin{array}{c}0.04^{* * *} \\
{[8.66]}\end{array}$ \\
\hline Rural & 0.31 & 0.31 & 0.42 & $\begin{array}{c}-0.11^{* * *} \\
{[-22.15]}\end{array}$ & 0.32 & 0.38 & $\begin{array}{c}-0.06^{* * *} \\
{[-13.23]}\end{array}$ \\
\hline B. Apartments & & & & & & & \\
\hline Number of transactions & 68,335 & 12,398 & 16,556 & & 9,558 & 11,138 & \\
\hline Price $(1,000 \mathrm{DKK})$ & $\begin{array}{c}1331.11 \\
(897.87)\end{array}$ & $\begin{array}{c}1207.52 \\
(755.11)\end{array}$ & $\begin{array}{c}1086.87 \\
(701.23)\end{array}$ & $\begin{array}{c}120.65^{* * *} \\
{[14.02]}\end{array}$ & $\begin{array}{c}1225.01 \\
(793.71)\end{array}$ & $\begin{array}{c}1125.28 \\
(763.58)\end{array}$ & $\begin{array}{l}99.73^{* * *} \\
{[9.20]}\end{array}$ \\
\hline Tax assessed value (1,000 DKK) & $\begin{array}{l}1082.95 \\
(751.09)\end{array}$ & $\begin{array}{c}976.23 \\
(643.79)\end{array}$ & $\begin{array}{c}892.46 \\
(597.12)\end{array}$ & $\begin{array}{c}83.77^{* * *} \\
{[11.42]}\end{array}$ & $\begin{array}{c}1001.14 \\
(679.38)\end{array}$ & $\begin{array}{c}921.57 \\
(648.33)\end{array}$ & $\begin{array}{l}79.57^{* * *} \\
{[8.61]}\end{array}$ \\
\hline Interior size $\left(\mathrm{m}^{2}\right)$ & $\begin{array}{c}76.43 \\
(29.61)\end{array}$ & $\begin{array}{l}71.91 \\
(22.85)\end{array}$ & $\begin{array}{c}69.02 \\
(23.55)\end{array}$ & $\begin{array}{c}2.88^{* * *} \\
{[10.45]}\end{array}$ & $\begin{array}{c}71.51 \\
(26.63)\end{array}$ & $\begin{array}{c}68.31 \\
(27.24)\end{array}$ & $\begin{array}{l}3.21^{* * *} \\
{[8.53]}\end{array}$ \\
\hline Building age (years) & $\begin{array}{c}63.55 \\
(37.13)\end{array}$ & $\begin{array}{c}61.61 \\
(36.63)\end{array}$ & $\begin{array}{c}61.47 \\
(36.20)\end{array}$ & $\begin{array}{c}0.14 \\
{[0.31]}\end{array}$ & $\begin{array}{c}63.89 \\
(36.36)\end{array}$ & $\begin{array}{c}63.34 \\
(36.71)\end{array}$ & $\begin{array}{l}0.55^{* * *} \\
{[1.08]}\end{array}$ \\
\hline Rooms (\#) & $\begin{array}{c}2.67 \\
(1.06)\end{array}$ & $\begin{array}{c}2.52 \\
(0.89)\end{array}$ & $\begin{array}{c}2.38 \\
(0.89)\end{array}$ & $\begin{array}{c}0.14^{* * *} \\
{[13.44]}\end{array}$ & $\begin{array}{c}2.49 \\
(1.00)\end{array}$ & $\begin{array}{c}2.35 \\
(0.98)\end{array}$ & $\begin{array}{c}0.14^{* * *} \\
{[10.49]}\end{array}$ \\
\hline Bathrooms (\#) & $\begin{array}{l}1.04 \\
(0.23)\end{array}$ & $\begin{array}{l}1.02 \\
(0.18)\end{array}$ & $\begin{array}{c}1.01 \\
(0.16)\end{array}$ & $\begin{array}{c}0.01^{* * *} \\
{[4.41]}\end{array}$ & $\begin{array}{l}1.03 \\
(0.2)\end{array}$ & $\begin{array}{c}1.02 \\
(0.19)\end{array}$ & $\begin{array}{c}0.01^{* * *} \\
{[2.82]}\end{array}$ \\
\hline Rural & 0.02 & 0.01 & 0.01 & $\begin{array}{c}0.00 \\
{[-0.45]}\end{array}$ & 0.01 & 0.01 & $\begin{array}{c}0.00 \\
{[1.20]}\end{array}$ \\
\hline
\end{tabular}




\section{Table 3: Hedonic model}

This table shows gender differences in sales prices by buyer and seller characteristics using a simple hedonic regression. The dependent variable is the log of transaction price in thousand year-2015 DKK. Data covers property transactions from 1994 to 2013, in which both the buyer and seller are stable households with a member between 18 and 65 years of age. Column (1) contains only houses; (2) only apartments; and (3) both houses and apartments. Additional controls include property characteristics, location indicators, quarter fixed effects, and year fixed effects. Robust standard errors are reported in parentheses. ${ }^{* *}$, **, and $*$ indicate statistical significance at the $1 \%, 5 \%$, and $10 \%$ levels, respectively. The linear test of whether female buyers and sellers trade at the same price is reported in the bottom of the table as p-values of the test.

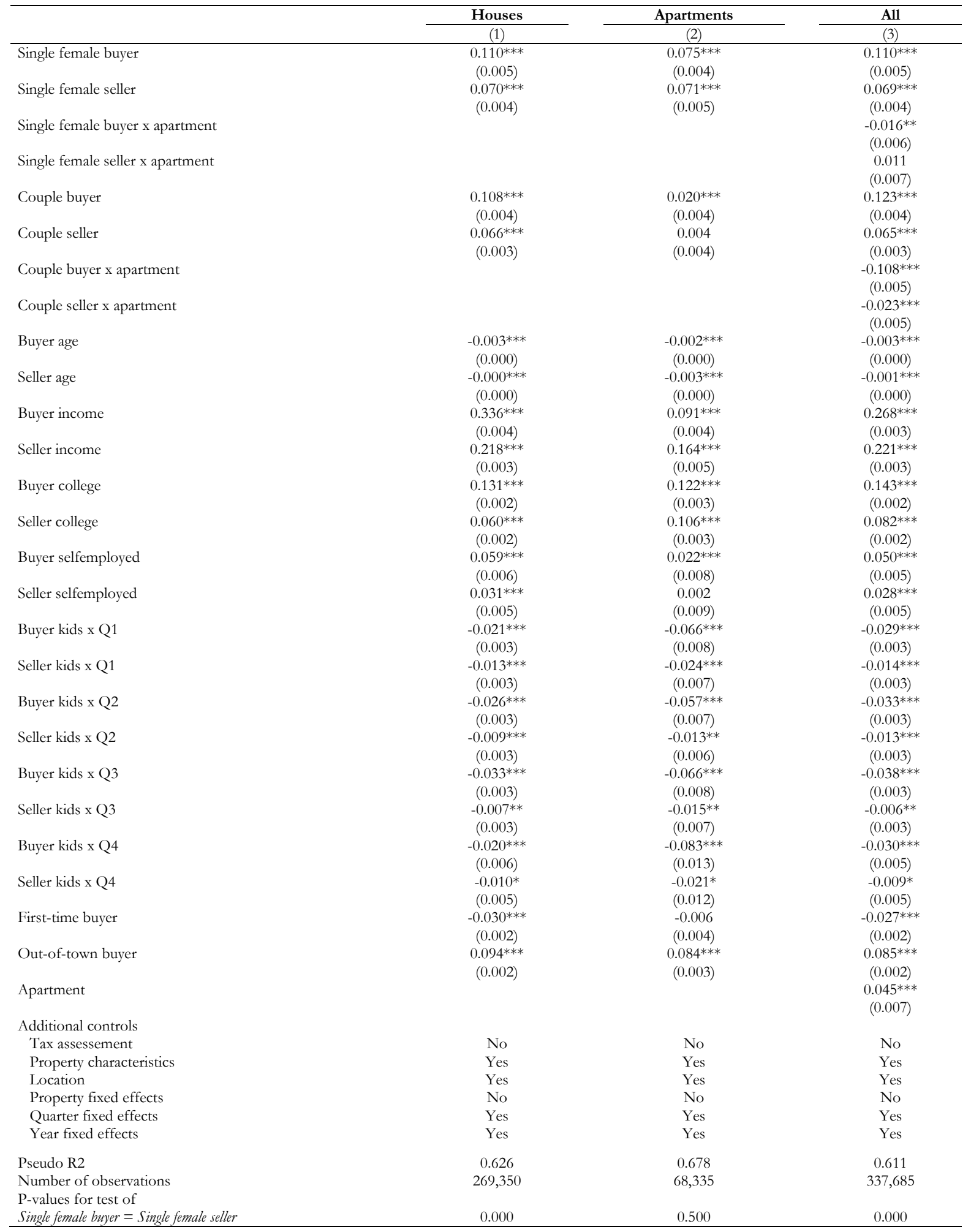




\section{Table 4: Gender differences in negotiation}

This table shows gender differences in negotiation and demand using the estimation methodology of Harding, Rosenthal, and Sirmans (2003). The dependent variable is the log of transaction price in thousand year-2015 DKK. Data covers property transactions from 1994 to 2013, in which both the buyer and seller are stable households with a member between 18 and 65 years of age. Columns (1), (4), and (7) have the coefficients on the differences, i.e., the negotiation effects. Columns (2), (5), and (8) have the coefficients on the sums, i.e., the demand effects. Columns (3), (6), and (9) show other controls. Columns (1)-(3) contain only houses; (4)-(6), only apartments; and (7)-(9), both houses and apartments. Additional controls include: property characteristics, location indicators, quarter fixed effects, and year fixed effects. Robust standard errors are reported in parentheses. ${ }^{* * *},{ }^{* *}$, and $*$ indicate statistical significance at the $1 \%, 5 \%$, and $10 \%$ levels, respectively.

\begin{tabular}{|c|c|c|c|c|c|c|c|c|c|}
\hline & \multicolumn{3}{|c|}{ Houses } & \multicolumn{3}{|c|}{ Apartments } & \multicolumn{3}{|c|}{ All } \\
\hline & $\begin{array}{c}\text { Negotiation } \\
\text { (1) }\end{array}$ & $\begin{array}{c}\text { Demand } \\
(2)\end{array}$ & $\begin{array}{c}\text { Other controls } \\
\text { (3) }\end{array}$ & $\begin{array}{c}\text { Negotiation } \\
(4)\end{array}$ & $\begin{array}{c}\text { Demand } \\
(5)\end{array}$ & $\begin{array}{l}\text { Other controls } \\
(6)\end{array}$ & $\begin{array}{c}\text { Negotiation } \\
(7)\end{array}$ & $\begin{array}{c}\text { Demand } \\
(8)\end{array}$ & $\begin{array}{c}\text { Other controls } \\
(9)\end{array}$ \\
\hline Single female & $\begin{array}{c}-0.020^{* * *} \\
(0.003)\end{array}$ & $\begin{array}{c}0.091 * * * \\
(0.003)\end{array}$ & & $\begin{array}{l}-0.002 \\
(0.003)\end{array}$ & $\begin{array}{c}0.073 * * * \\
(0.003)\end{array}$ & & $\begin{array}{c}-0.021^{* * *} \\
(0.003)\end{array}$ & $\begin{array}{c}0.090^{* * *} \\
(0.003)\end{array}$ & \\
\hline Single female $\mathrm{x}$ apartment & & & & & & & $\begin{array}{c}0.014 * * * \\
(0.005)\end{array}$ & $\begin{array}{l}-0.003 \\
(0.005)\end{array}$ & \\
\hline Couple & $\begin{array}{c}-0.021 * * * \\
(0.002)\end{array}$ & $\begin{array}{c}0.087 * * * \\
(0.002)\end{array}$ & & $\begin{array}{c}-0.007 * * \\
(0.003)\end{array}$ & $\begin{array}{c}0.011 * * * \\
(0.003)\end{array}$ & & $\begin{array}{c}-0.028 * * * \\
(0.002)\end{array}$ & $\begin{array}{c}0.094 * * * \\
(0.002)\end{array}$ & \\
\hline Couple $\mathrm{x}$ apartment & & & & & & & $\begin{array}{c}0.043^{* * *} \\
(0.004)\end{array}$ & $\begin{array}{c}-0.066^{* * *} \\
(0.004)\end{array}$ & \\
\hline Age & $\begin{array}{c}0.001 * * * \\
(0.000)\end{array}$ & $\begin{array}{c}-0.002 * * * \\
(0.000)\end{array}$ & & $\begin{array}{c}-0.000 * * * \\
(0.000)\end{array}$ & $\begin{array}{c}-0.002 * * * \\
(0.000)\end{array}$ & & $\begin{array}{c}0.001 * * * \\
(0.000)\end{array}$ & $\begin{array}{c}-0.002 * * * \\
(0.000)\end{array}$ & \\
\hline Income & $\begin{array}{c}-0.061 * * * \\
(0.003)\end{array}$ & $\begin{array}{c}0.279 * * * \\
(0.002)\end{array}$ & & $\begin{array}{c}0.035^{* * *} \\
(0.003)\end{array}$ & $\begin{array}{c}0.130 * * * \\
(0.003)\end{array}$ & & $\begin{array}{c}-0.026 * * * \\
(0.002)\end{array}$ & $\begin{array}{c}0.246 * * * \\
(0.002)\end{array}$ & \\
\hline College & $\begin{array}{c}-0.036 * * * \\
(0.002)\end{array}$ & $\begin{array}{c}0.097 * * * \\
(0.002)\end{array}$ & & $\begin{array}{c}-0.010 * * * \\
(0.002)\end{array}$ & $\begin{array}{c}0.116^{* * *} \\
(0.002)\end{array}$ & & $\begin{array}{c}-0.032 * * * \\
(0.001)\end{array}$ & $\begin{array}{c}0.113 * * * \\
(0.001)\end{array}$ & \\
\hline Self-employed & $\begin{array}{c}-0.013 * * * \\
(0.004)\end{array}$ & $\begin{array}{c}0.044 * * * \\
(0.004)\end{array}$ & & $\begin{array}{l}-0.010 \\
(0.006)\end{array}$ & $\begin{array}{l}0.011^{*} \\
(0.006)\end{array}$ & & $\begin{array}{c}-0.011 * * * \\
(0.003)\end{array}$ & $\begin{array}{c}0.038 * * * \\
(0.003)\end{array}$ & \\
\hline School-age children $\mathrm{x} 1$ st quarter & $\begin{array}{l}0.005 * * \\
(0.002)\end{array}$ & $\begin{array}{c}-0.017 * * * \\
(0.002)\end{array}$ & & $\begin{array}{c}0.021 * * * \\
(0.005)\end{array}$ & $\begin{array}{c}-0.046 * * * \\
(0.005)\end{array}$ & & $\begin{array}{c}0.008 * * * \\
(0.002)\end{array}$ & $\begin{array}{c}-0.022 * * * \\
(0.002)\end{array}$ & \\
\hline School-age children $\mathrm{x}$ 2nd quarter & $\begin{array}{c}0.009 * * * \\
(0.002)\end{array}$ & $\begin{array}{c}-0.018 * * * \\
(0.002)\end{array}$ & & $\begin{array}{c}0.022^{* * *} \\
(0.005)\end{array}$ & $\begin{array}{c}-0.036 * * * \\
(0.005)\end{array}$ & & $\begin{array}{c}0.010^{* * *} \\
(0.002)\end{array}$ & $\begin{array}{c}-0.024 * * * \\
(0.002)\end{array}$ & \\
\hline School-age children $\times$ 3rd quarter & $\begin{array}{c}0.013^{* * *} \\
(0.002)\end{array}$ & $\begin{array}{c}-0.021 * * * \\
(0.002)\end{array}$ & & $\begin{array}{c}0.026^{* * *} \\
(0.005)\end{array}$ & $\begin{array}{c}-0.042 * * * \\
(0.005)\end{array}$ & & $\begin{array}{c}0.016^{* * *} \\
(0.002)\end{array}$ & $\begin{array}{c}-0.023 * * * \\
(0.002)\end{array}$ & \\
\hline School-age children $\mathrm{x} 4$ th quarter & $\begin{array}{l}0.005 \\
(0.004)\end{array}$ & $\begin{array}{c}-0.015^{* * *} \\
(0.004)\end{array}$ & & $\begin{array}{c}0.031 * * * \\
(0.009)\end{array}$ & $\begin{array}{c}-0.053^{* * *} \\
(0.009)\end{array}$ & & $\begin{array}{c}0.011^{* * *} \\
(0.004)\end{array}$ & $\begin{array}{c}-0.020 * * * \\
(0.003)\end{array}$ & \\
\hline First-time buyer & & & $\begin{array}{c}-0.032 * * * \\
(0.002)\end{array}$ & & & $\begin{array}{c}-0.008^{* *} \\
(0.004)\end{array}$ & & & $\begin{array}{c}-0.029 * * * \\
(0.002)\end{array}$ \\
\hline Out-of-town buyer & & & $\begin{array}{c}0.093^{* * *} \\
(0.002)\end{array}$ & & & $\begin{array}{c}0.084^{* * *} \\
(0.003)\end{array}$ & & & $\begin{array}{c}0.085^{* * *} \\
(0.002)\end{array}$ \\
\hline Apartment & & & & & & & & & $\begin{array}{c}0.043^{* * *} \\
(0.007)\end{array}$ \\
\hline Constant & & & $\begin{array}{c}6.318^{* * *} \\
(0.008)\end{array}$ & & & $\begin{array}{c}5.920 * * * \\
(0.014)\end{array}$ & & & $\begin{array}{c}6.225^{* * *} \\
(0.008)\end{array}$ \\
\hline $\begin{array}{l}\text { Additional controls: } \\
\text { Property characteristics }\end{array}$ & & Yes & & & & & & & \\
\hline $\begin{array}{l}\text { Property characteristics } \\
\text { Location }\end{array}$ & & $\begin{array}{l}\text { Yes } \\
\text { Yes }\end{array}$ & & & $\begin{array}{l}\text { Yes } \\
\text { Yes }\end{array}$ & & & $\begin{array}{l}\text { Yes } \\
\text { Yes }\end{array}$ & \\
\hline Property fixed effects & & No & & & No & & & No & \\
\hline Quarter fixed effects & & Yes & & & Yes & & & Yes & \\
\hline Year fixed effects & & Yes & & & Yes & & & Yes & \\
\hline Pseudo R2 & & 0.626 & & & 0.679 & & & 0.611 & \\
\hline Number of observations & & 269,350 & & & 68,335 & & & 337,685 & \\
\hline
\end{tabular}


Table 5: Gender differences in negotiation controlling for tax-assessed value

This table shows gender differences in negotiation and demand using the estimation methodology of Harding, Rosenthal, and Sirmans (2003), adding controls for the tax-assessed value of the property. The dependent variable is the log of transaction price in thousand year-2015 DKK. Data covers property transactions from 1994 to 2013 , in which both the buyer and seller are stable households with a member between 18 and 65 years of age. Columns (1), (4), and (7) have the coefficients on the differences, i.e., the negotiation effects. Columns (2), (5), and (8) have the coefficients on the sums, i.e., the demand effects. Columns (1)-(3) contain only houses; (4)-(6), only apartments; and (7)-(9), both houses and apartments. Additional controls include: property characteristics, location indicators, quarter fixed effects, and year fixed effects. Robust standard errors are reported in parentheses. $* * *, * *$, and * indicate statistical significance at the $1 \%, 5 \%$, and $10 \%$ levels, respectively.

\begin{tabular}{|c|c|c|c|c|c|c|c|c|c|}
\hline & \multicolumn{3}{|c|}{ Houses } & \multicolumn{3}{|c|}{ Apartments } & \multicolumn{3}{|c|}{ All } \\
\hline & $\begin{array}{l}\text { Negotiation } \\
\text { (1) }\end{array}$ & $\begin{array}{l}\text { Demand } \\
\text { (2) }\end{array}$ & $\begin{array}{l}\text { Other controls } \\
\text { (3) }\end{array}$ & $\begin{array}{l}\text { Negotiation } \\
\text { (4) }\end{array}$ & $\begin{array}{l}\text { Demand } \\
(5)\end{array}$ & $\begin{array}{l}\text { Other controls } \\
\text { (6) }\end{array}$ & $\begin{array}{c}\text { Negotiation } \\
(7)\end{array}$ & $\begin{array}{c}\text { Demand } \\
(8)\end{array}$ & $\begin{array}{l}\text { Other controls } \\
\text { (9) }\end{array}$ \\
\hline Single female & $\begin{array}{c}-0.010 * * * \\
(0.002)\end{array}$ & $\begin{array}{c}0.053 * * * \\
(0.002)\end{array}$ & & $\begin{array}{l}-0.001 \\
(0.002)\end{array}$ & $\begin{array}{c}0.026^{* * *} \\
(0.002)\end{array}$ & & $\begin{array}{c}-0.010^{* * *} \\
(0.002)\end{array}$ & $\begin{array}{c}0.053^{* * *} \\
(0.002)\end{array}$ & \\
\hline Single female $\mathrm{x}$ apartment & & & & & & & $\begin{array}{l}0.007 * * \\
(0.003)\end{array}$ & $\begin{array}{c}-0.026^{* * *} \\
(0.003)\end{array}$ & \\
\hline Couple & $\begin{array}{c}0.006^{* * *} \\
(0.002)\end{array}$ & $\begin{array}{c}0.073 * * * \\
(0.001)\end{array}$ & & $\begin{array}{c}0.002 \\
(0.002)\end{array}$ & $\begin{array}{c}0.006^{* * *} \\
(0.002)\end{array}$ & & $\begin{array}{l}0.004 * * \\
(0.002)\end{array}$ & $\begin{array}{c}0.075^{* * *} \\
(0.001)\end{array}$ & \\
\hline Couple $\mathrm{x}$ apartment & & & & & & & $\begin{array}{l}0.005 * * \\
(0.002)\end{array}$ & $\begin{array}{c}-0.074 * * * \\
(0.002)\end{array}$ & \\
\hline Age & $\begin{array}{c}-0.000 * * * \\
(0.000)\end{array}$ & $\begin{array}{c}-0.001 * * * \\
(0.000)\end{array}$ & & $\begin{array}{c}-0.000 * * * \\
(0.000)\end{array}$ & $\begin{array}{c}-0.001 * * * \\
(0.000)\end{array}$ & & $\begin{array}{c}-0.000^{* * *} \\
(0.000)\end{array}$ & $\begin{array}{c}-0.001 * * * \\
(0.000)\end{array}$ & \\
\hline Income & $\begin{array}{c}-0.020 * * * \\
(0.001)\end{array}$ & $\begin{array}{c}0.079 * * * \\
(0.001)\end{array}$ & & $\begin{array}{c}0.018^{* * *} \\
(0.002)\end{array}$ & $\begin{array}{c}0.045^{* * *} \\
(0.002)\end{array}$ & & $\begin{array}{c}-0.006 * * * \\
(0.001)\end{array}$ & $\begin{array}{c}0.069 * * * \\
(0.001)\end{array}$ & \\
\hline College & $\begin{array}{c}-0.014 * * * \\
(0.001)\end{array}$ & $\begin{array}{c}0.026^{* * *} \\
(0.001)\end{array}$ & & $\begin{array}{c}-0.008^{* * *} \\
(0.001)\end{array}$ & $\begin{array}{c}0.025^{* * *} * \\
(0.001)\end{array}$ & & $\begin{array}{c}-0.014^{* * *} \\
(0.001)\end{array}$ & $\begin{array}{c}0.026 * * * \\
(0.001)\end{array}$ & \\
\hline Self-employed & $\begin{array}{c}-0.006^{* *} \\
(0.002)\end{array}$ & $\begin{array}{c}0.019 * * * \\
(0.002)\end{array}$ & & $\begin{array}{c}0.001 \\
(0.004)\end{array}$ & $\begin{array}{c}0.001 \\
(0.004)\end{array}$ & & $\begin{array}{l}-0.003 \\
(0.002)\end{array}$ & $\begin{array}{c}0.014 * * * \\
(0.002)\end{array}$ & \\
\hline School-age children x 1st quarter & $\begin{array}{l}-0.002 \\
(0.001)\end{array}$ & $\begin{array}{c}-0.017 * * * \\
(0.001)\end{array}$ & & $\begin{array}{c}0.003 \\
(0.003)\end{array}$ & $\begin{array}{c}-0.026 * * * \\
(0.003)\end{array}$ & & $\begin{array}{l}-0.000 \\
(0.001)\end{array}$ & $\begin{array}{c}-0.016 * * * \\
(0.001)\end{array}$ & \\
\hline School-age children x 2 nd quarter & $\begin{array}{c}-0.004 * * * \\
(0.001)\end{array}$ & $\begin{array}{c}-0.019 * * * \\
(0.001)\end{array}$ & & $\begin{array}{c}0.002 \\
(0.003)\end{array}$ & $\begin{array}{c}-0.024 * * * \\
(0.003)\end{array}$ & & $\begin{array}{c}-0.002^{* *} \\
(0.001)\end{array}$ & $\begin{array}{c}-0.019 * * * \\
(0.001)\end{array}$ & \\
\hline School-age children $\times 3$ rd quarter & $\begin{array}{l}-0.001 \\
(0.001)\end{array}$ & $\begin{array}{c}-0.019 * * * \\
(0.001)\end{array}$ & & $\begin{array}{c}0.007 * * \\
(0.003)\end{array}$ & $\begin{array}{c}-0.025^{* * *} \\
(0.003)\end{array}$ & & $\begin{array}{c}0.001 \\
(0.001)\end{array}$ & $\begin{array}{c}-0.019 * * * \\
(0.001)\end{array}$ & \\
\hline School-age children $\mathrm{x}$ 4th quarter & $\begin{array}{l}-0.004 \\
(0.002)\end{array}$ & $\begin{array}{c}-0.016^{* * *} \\
(0.002)\end{array}$ & & $\begin{array}{l}0.010 * * \\
(0.005)\end{array}$ & $\begin{array}{c}-0.030^{* * *} \\
(0.005)\end{array}$ & & $\begin{array}{l}-0.001 \\
(0.002)\end{array}$ & $\begin{array}{c}-0.017 * * * \\
(0.002)\end{array}$ & \\
\hline First-time buyer & & & $\begin{array}{c}-0.008^{* * *} \\
(0.001)\end{array}$ & & & $\begin{array}{c}0.001 \\
(0.002)\end{array}$ & & & $\begin{array}{c}-0.007 * * * \\
(0.001)\end{array}$ \\
\hline Out-of-town buyer & & & $\begin{array}{c}0.017 * * * \\
(0.001)\end{array}$ & & & $\begin{array}{c}0.019 * * * \\
(0.002)\end{array}$ & & & $\begin{array}{c}0.018^{* * *} \\
(0.001)\end{array}$ \\
\hline Apartment & & & & & & & & & $\begin{array}{c}0.086 * * * \\
(0.004)\end{array}$ \\
\hline Assessed value (log) & & & $\begin{array}{c}0.917 * * * \\
(0.003)\end{array}$ & & & $\begin{array}{c}0.883^{* * *} \\
(0.004)\end{array}$ & & & $\begin{array}{c}0.914 * * * \\
(0.002)\end{array}$ \\
\hline Constant & & & $\begin{array}{c}0.643 * * * \\
(0.019)\end{array}$ & & & $\begin{array}{c}0.940 * * * \\
(0.023)\end{array}$ & & & $\begin{array}{c}0.675 * * * \\
(0.015)\end{array}$ \\
\hline Additional controls: & & & & & & & & & \\
\hline Property characteristics & & Yes & & & Yes & & & Yes & \\
\hline Location & & Yes & & & Yes & & & Yes & \\
\hline Property fixed effects & & No & & & No & & & No & \\
\hline Quarter fixed effects & & Yes & & & Yes & & & Yes & \\
\hline Year fixed effects & & Yes & & & Yes & & & Yes & \\
\hline $\begin{array}{l}\text { Pseudo R2 } \\
\text { Number of observations }\end{array}$ & & $\begin{array}{c}0.869 \\
269,350\end{array}$ & & & $\begin{array}{l}0.891 \\
68,335 \\
\end{array}$ & & & $\begin{array}{c}0.871 \\
337,685\end{array}$ & \\
\hline
\end{tabular}




\section{Table 6: Repeated sales}

This table presents results where we control for time invariant unobserved heterogeneity by including property fixed effect within a repeated sales sample, still using the estimation methodology of Harding, Rosenthal, and Sirmans (2003). The dependent variable is the log of transaction price in thousand year-2015 DKK. Data covers property transactions from 1994 to 2013 , in which both the buyer and seller are stable households with a member between 18 and 65 years of age, and the property is traded more than once during the time period. Columns (1), (4), and (7) have the coefficients on the differences, i.e., the negotiation effects. Columns (2), (5), and (8) have the coefficients on the sums, i.e., the demand effects. Columns (1)-(3) contain only houses; (4)-(6), only apartments; and

(7)-(9), both houses and apartments. Additional controls include: quarter fixed effects, and year fixed effects. Robust standard errors are reported in parentheses. $* * *, * *$, and $*$ indicate statistical significance at the $1 \%, 5 \%$, and $10 \%$ levels, respectively.

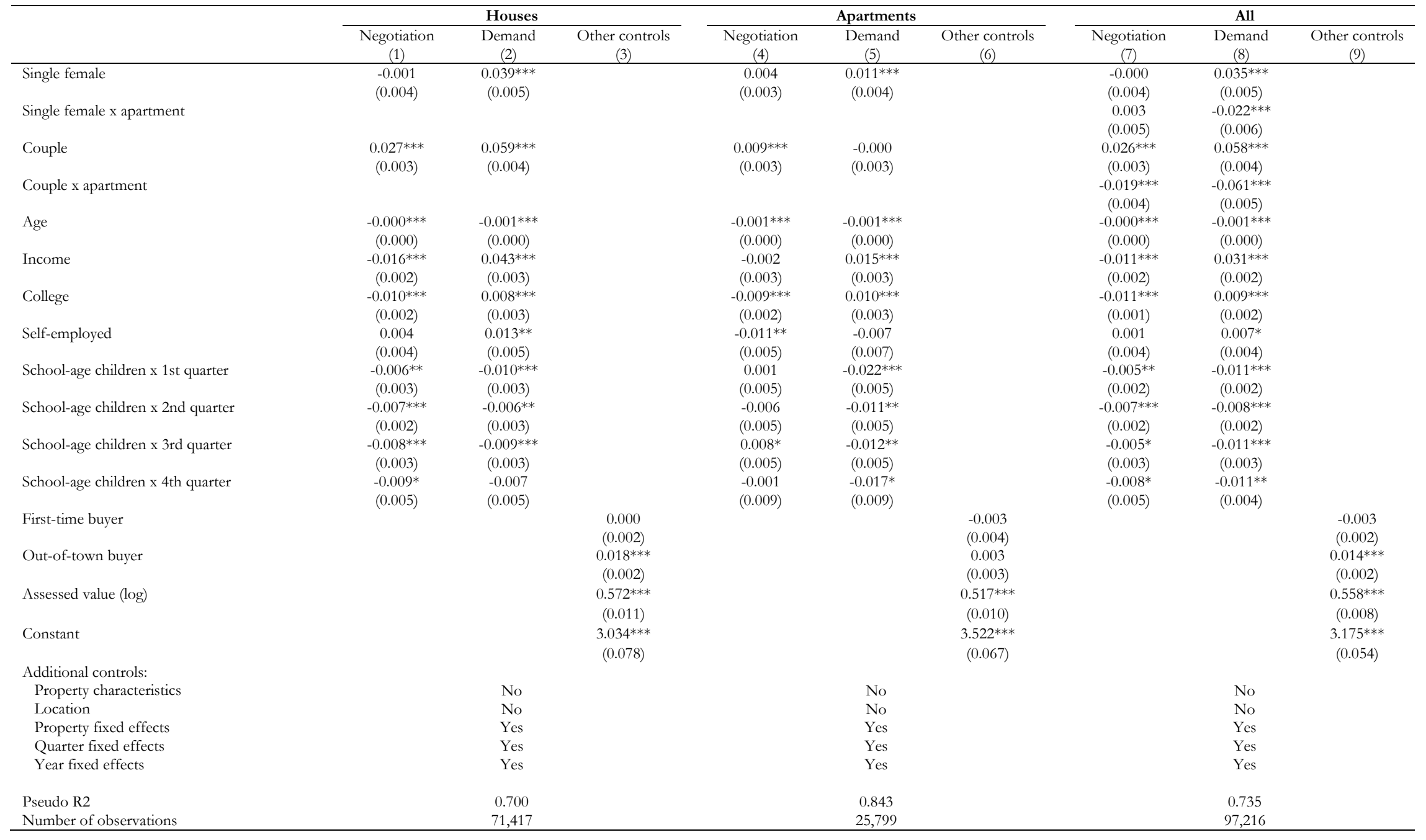




\section{Table 7: Property characteristics of death sales}

This table shows characteristics of properties sold after the death of the owner in the years 1994 to 2013, separately for houses and apartments. Price is the realized sale price, and assessed value is the assessed value of the property from the Danish tax authorities prior to the sales. Both prices and assessed value are measured in thousand year-2015 DKK. Interior size and Lot size are measured in square meters. House age and building age are measured in years. Rooms and batbrooms are count variables. Rural indicates a rural area. Standard deviations are presented in parentheses for non-indicator variables. $t$ statistics are in brackets. ${ }^{* * *}$ and ${ }^{* *}$ indicate significance at the $1 \%$ and $5 \%$ levels, respectively.

\begin{tabular}{|c|c|c|c|c|}
\hline \multirow{3}{*}{ A. Houses } & \multirow[b]{2}{*}{ All } & \multicolumn{3}{|c|}{ Sellers } \\
\hline & & \multirow[t]{2}{*}{$\begin{array}{c}\text { Women } \\
\text { (1) }\end{array}$} & \multirow[t]{2}{*}{$\begin{array}{c}\text { Men } \\
(2)\end{array}$} & \multirow[t]{2}{*}{$\begin{array}{c}\text { Difference } \\
(1)-(2)\end{array}$} \\
\hline & & & & \\
\hline Number of transactions & 12,633 & 1,667 & 1,929 & \\
\hline \multirow[t]{2}{*}{ Price $(1,000 \mathrm{DKK})$} & 1208.83 & 1273.27 & 1187.81 & $85.46^{* * *}$ \\
\hline & $(899.52)$ & $(987.47)$ & $(925.35)$ & {$[2.68]$} \\
\hline \multirow[t]{2}{*}{ Assessed value (1,000 DKK) } & 1145.24 & 1231.85 & 1174.58 & $57.28^{*}$ \\
\hline & $(822.25)$ & $(883.52)$ & (891.54) & [1.93] \\
\hline \multirow[t]{2}{*}{ Interior size $\left(\mathrm{m}^{2}\right)$} & 112.57 & 113.38 & 111.12 & $2.27^{*}$ \\
\hline & $(37.61)$ & $(39.35)$ & $(38.12)$ & {$[1.75]$} \\
\hline \multirow[t]{2}{*}{ Lot size $\left(\mathrm{m}^{2}\right)$} & 1001.19 & 1035.33 & 984.56 & 50.78 \\
\hline & $(2289.26)$ & $(2760.94)$ & $(890.38)$ & {$[0.76]$} \\
\hline \multirow[t]{2}{*}{ House age (years) } & 55.11 & 57.35 & 56.92 & 0.42 \\
\hline & $(33.51)$ & $(35.54)$ & $(34.2)$ & {$[0.36]$} \\
\hline \multirow[t]{2}{*}{ Rooms (\#) } & 4.12 & 4.18 & 4.10 & $0.09^{* *}$ \\
\hline & $(1.19)$ & $(1.26)$ & $(1.17)$ & {$[2.10]$} \\
\hline \multirow[t]{2}{*}{ Bathrooms (\#) } & 1.24 & 1.27 & 1.23 & $0.04^{* *}$ \\
\hline & $(0.49)$ & $(0.54)$ & $(0.48)$ & {$[2.33]$} \\
\hline \multirow[t]{2}{*}{ Rural } & 0.24 & 0.24 & 0.26 & -0.02 \\
\hline & & & & {$[-1.39]$} \\
\hline \multicolumn{5}{|l|}{ B. Apartments } \\
\hline Number of transactions & 1,320 & 240 & 195 & \\
\hline \multirow[t]{2}{*}{ Price $(1,000 \mathrm{DKK})$} & 1252.69 & 1189.94 & 1271.71 & -81.77 \\
\hline & $(844.76)$ & $(810.34)$ & $(856.59)$ & {$[-1.02]$} \\
\hline \multirow[t]{2}{*}{ Assessed value (1,000 DKK) } & 1162.78 & 1135.50 & 1152.69 & -17.20 \\
\hline & (814.31) & (787.91) & $(718.3)$ & {$[-0.24]$} \\
\hline \multirow[t]{2}{*}{ Interior size $\left(\mathrm{m}^{2}\right)$} & 82.68 & 81.70 & 82.04 & -0.34 \\
\hline & $(26.42)$ & $(27.68)$ & $(27.99)$ & {$[-0.13]$} \\
\hline \multirow[t]{2}{*}{ Building age (years) } & 50.53 & 55.05 & 54.26 & 0.79 \\
\hline & $(33.71)$ & $(32.76)$ & $(38.21)$ & {$[0.23]$} \\
\hline \multirow[t]{2}{*}{ Rooms (\#) } & 2.91 & 2.85 & 2.90 & -0.05 \\
\hline & $(0.99)$ & $(1.03)$ & $(1.02)$ & {$[-0.49]$} \\
\hline \multirow[t]{2}{*}{ Bathrooms (\#) } & 1.05 & 1.04 & 1.03 & 0.01 \\
\hline & $(0.24)$ & $(0.23)$ & $(0.19)$ & {$[0.58]$} \\
\hline \multirow[t]{2}{*}{ Rural } & 0.02 & 0.03 & 0.01 & 0.02 \\
\hline & & & & {$[1.38]$} \\
\hline
\end{tabular}




\section{Table 8: Hedonic model when selling inherited properties}

This table shows gender differences in sales prices by buyer and seller characteristics when selling inherited properties using a simple hedonic regression. The dependent variable is the $\log$ of transaction price in thousand year-2015 DKK. Data covers property transactions from 1994 to 2013 , in which both the buyer and seller are stable households with a member between 18 and 65 years of age. Column (1) contains only houses; (2) only apartments; and (3) both houses and apartments. Additional controls include couple buyer and couple seller, buyer and seller characteristics, property characteristics, location indicators, quarter fixed effects, and year fixed effects. Only coefficients on the variable of interest, female buyers and female sellers, are reported. Robust standard errors are reported in parentheses. *** indicates statistical significance at the $1 \%$ level. The linear test of whether female buyers and sellers trade at the same price is reported in the bottom of the table as p-values of the test.

\begin{tabular}{|c|c|c|c|}
\hline & $\begin{array}{c}\text { Houses } \\
(1) \\
\end{array}$ & $\begin{array}{c}\text { Apartment } \\
\text { (2) }\end{array}$ & $\begin{array}{l}\text { All } \\
(3) \\
\end{array}$ \\
\hline \multirow[t]{2}{*}{ Single female buyer } & $0.036^{* * *}$ & 0.004 & $0.036^{* * *}$ \\
\hline & $(0.010)$ & $(0.020)$ & $(0.010)$ \\
\hline \multirow[t]{2}{*}{ Single female seller } & 0.014 & -0.016 & 0.014 \\
\hline & $(0.011)$ & $(0.022)$ & $(0.011)$ \\
\hline \multirow[t]{2}{*}{ Single female buyer $\mathrm{x}$ apartment } & & & -0.031 \\
\hline & & & $(0.022)$ \\
\hline \multirow[t]{2}{*}{ Single female seller $\mathrm{x}$ apartment } & & & -0.040 \\
\hline & & & $(0.026)$ \\
\hline \multicolumn{4}{|l|}{ Additional controls } \\
\hline Buyer and seller characteristics & Yes & Yes & Yes \\
\hline Assessed value & Yes & Yes & Yes \\
\hline Property characteristics & Yes & Yes & Yes \\
\hline Location & Yes & Yes & Yes \\
\hline Property fixed effects & No & No & No \\
\hline Quarter fixed effects & Yes & Yes & Yes \\
\hline Year fixed effects & Yes & Yes & Yes \\
\hline Pseudo R2 & 0.840 & 0.836 & 0.837 \\
\hline $\begin{array}{l}\text { Number of observations } \\
\text { P-values for test of }\end{array}$ & 12,633 & 1,320 & 13,953 \\
\hline Single female buyer $=$ Single female seller & 0.143 & 0.486 & 0.149 \\
\hline
\end{tabular}

